.Supporting Information for:

\title{
.Contingency and Serendipity in the Reactions of Fischer Carbene Complexes with Conjugated Triynes.
}

\author{
May Xiao-Wu Jiang, Manish Rawat and William D. Wulff * \\ Department of Chemistry \\ Michigan State University \\ East Lansing, MI 48824
}

\section{Chapter S General Information}

Unless and otherwise indicated, all common reagents and solvents were used as obtained from commercial suppliers without further purification. Prior to use, tetrahydrofuran and diethyl ether were distilled from $\mathrm{Na}$ /benzophenone ketyl, toluene was distilled from $\mathrm{Na}$ and methylene chloride was prepared by distillation from calcium hydride. Routine NMR spectra were recorded on $300 \mathrm{MHz}, 500 \mathrm{MHz}$ INOVA and VXR instruments. Both low and high resolution mass spectra were obtained from the Michigan State University Mass Spectrometry Facility. Elemental analyses were done by the Michigan State University Elemental Analysis Facility.

Preparation of Triynes $4 a-4 d$.

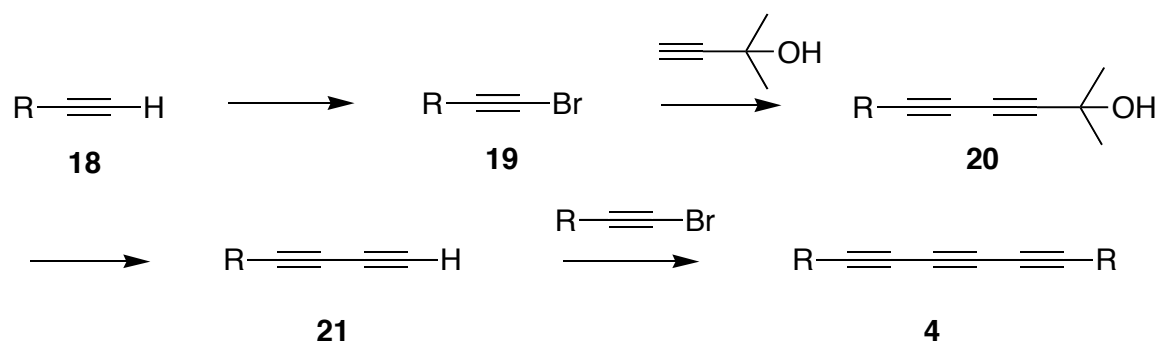

\section{General Procedure for the Synthesis of Alkynyl Bromides 19:}

Procedure $\mathrm{I}:{ }^{1}$ A solution of $\mathrm{NaOBr}$ was prepared by mixing a solution of $\mathrm{NaOH}$ $(6 \mathrm{~g}, 150 \mathrm{mmol})$ in $\mathrm{H}_{2} \mathrm{O}(25 \mathrm{~mL})$ with $\mathrm{Br}_{2}(1.6 \mathrm{~mL}, 31 \mathrm{mmol})$ at $0{ }^{\circ} \mathrm{C}$. To this solution was added phenyl acetylene $(5.0 \mathrm{~g}, 49 \mathrm{mmol})$ dropwise at $0{ }^{\circ} \mathrm{C}$ and after addition the reaction mixture was stirred at room temperature for 2 hours. Then the reaction mixture was extracted with ether and the extract was dried over $\mathrm{MgSO}_{4}$. The solvent was removed by rotovapor and the residue was distilled under reduced pressure to give the alkynyl bromide 19.

Procedure II: ${ }^{2}$ To a solution of triisopropylsilylacetylene $(0.55 \mathrm{~g}, 3 \mathrm{mmol})$ in acetone $(20 \mathrm{~mL})$ was added $\mathrm{N}$-bromosuccinnimde $(0.62 \mathrm{~g}, 3.5 \mathrm{mmol})$ and silver nitrate $(50 \mathrm{mg}$, $0.3 \mathrm{mmol}$ ) in order. The mixture was stirred at room temperature for 2 hours, poured into icewater and extracted with pentane. The extract was washed with $\mathrm{H}_{2} \mathrm{O}$ and brine and dried over 
$\mathrm{MgSO}_{4}$. After the solvent was removed by rotovapor, the alkynyl bromide was clean enough for further use without purification.

Alkynyl Bromide 19a. $\mathrm{R}=\mathrm{C}_{6} \mathrm{H}_{5}$. Procedure I: $88 \%$ yield. Clear colorless liquid. Distilled at $72{ }^{\circ} \mathrm{C} / 2.6 \mathrm{mmHg} .{ }^{1} \mathrm{H}\left(300 \mathrm{MHz} \mathrm{CDCl}_{3}\right): \delta 7.26-7.44(\mathrm{~m}, 5 \mathrm{H}) ;{ }^{13} \mathrm{C}(75 \mathrm{MHz}$, $\left.\mathrm{CDCl}_{3}\right): \delta 49.8,80.0,122.7,128.3,128.7,132.0$.

Alkynyl Bromide 19b. $\mathrm{R}=1$-adamantyl. Procedure II: $89 \%$ yield. White solid. $\mathrm{Mp}=$ $130-133{ }^{\circ} \mathrm{C} . \mathrm{R}_{\mathrm{f}}=0.71$ (hexanes : ethyl acetate $\left.=10: 1\right) .{ }^{1} \mathrm{H}\left(300 \mathrm{MHz}, \mathrm{CDCl}_{3}\right): \delta 1.65-1.66(\mathrm{~m}$, $6 \mathrm{H}), 1.84-1.85(\mathrm{~m}, 6 \mathrm{H}), 1.93(\mathrm{bs}, 3 \mathrm{H}) ;{ }^{13} \mathrm{C}\left(75 \mathrm{MHz}, \mathrm{CDCl}_{3}\right): \delta$ 27.85, 30.90, 36.22, 37.40, 42.47, 88.20; IR (neat): 2905.2, 2851.2, 1448.7, 1344.6, 1315.6, 1099.6, $983.8 \mathrm{~cm}^{-1}$; mass spectrum (EI) $\mathrm{m} / z$ (\% rel. int.) $240 \mathrm{M}^{+}\left(13,{ }^{81} \mathrm{Br}\right), 238 \mathrm{M}^{+}\left(12,{ }^{79} \mathrm{Br}\right), 159$ (100), 131 (50), 117 (87), 102 (44), 91 (86), calcd. for $\mathrm{C}_{12} \mathrm{H}_{15}{ }^{79} \mathrm{Br} \mathrm{m} / z$ 238.0357, measd 238.0370. Anal. Calcd. for $\mathrm{C}_{12} \mathrm{H}_{15} \mathrm{Br}$ : C, 60.27; H, 6.32. Found: C, 60.13; H, 6.21.

Alkynyl Bromide 19c. $\mathrm{R}=$ t-butyldimethylsilyl (TBS). Procedure II: $98 \%$ yield. Clear colorless liquid. ${ }^{1} \mathrm{H}\left(300 \mathrm{MHz}, \mathrm{CDCl}_{3}\right): \delta 0.10(\mathrm{~s}, 6 \mathrm{H}), 0.92(\mathrm{~s}, 9 \mathrm{H}) ;{ }^{13} \mathrm{C}\left(75 \mathrm{MHz}, \mathrm{CDCl}_{3}\right): \delta$ 4.76, 16.66, 25.94, 61.44, 85.32.

Alkynyl Bromide 19d. $\mathrm{R}=$ triisopropylsilyl (TIPS). Procedure II: $96 \%$ yield. Clear colorless liquid. ${ }^{1} \mathrm{H}\left(300 \mathrm{MHz}, \mathrm{CDCl}_{3}\right): \delta 1.05(\mathrm{~s}, 21 \mathrm{H}) ;{ }^{13} \mathrm{C}\left(75 \mathrm{MHz}, \mathrm{CDCl}_{3}\right): \delta 11.27,18.48$, $61.71,83.40$.

\section{General Procedure for the Synthesis of Diyne Alcohol 20:}

To a mixture of $\mathrm{MeOH}(10 \mathrm{~mL})$ and $\mathrm{H}_{2} \mathrm{O}(5 \mathrm{~mL})$ were added n-butylamine $(120$ mmol), 2-methyl-3-butyne-2-ol (80 mmol), copper (I) chloride (6 mmol) and hydroxyaminehydrochloride $(12 \mathrm{mmol})$ in order. The proper alkynyl bromide 19 (40 mmol) was diluted with $5 \mathrm{~mL} \mathrm{MeOH}$ and was added dropwise to the mixture. Then the reaction mixture was stirred at room temperature for 20-30 hours. The reaction was quenched with $\mathrm{H}_{2} \mathrm{O}$ and extracted with ether. The organic layer was washed with $\mathrm{H}_{2} \mathrm{O}$, brine and dried with $\mathrm{MgSO}_{4}$. After the solvent was removed by rotovapor, the product was purified by column chromatograph with a $10: 1$ mixture of hexanes to ethyl acetate.

Diyne Alcohol 20a: $\mathrm{R}=\mathrm{C}_{6} \mathrm{H}_{5}$. Yield $96 \%$. White fluffy solid. $\mathrm{Mp}=57-58{ }^{\circ} \mathrm{C}$, lit. ${ }^{3} 56{ }^{\circ} \mathrm{C}$. $\mathrm{R}_{\mathrm{f}}=0.37$ (hexanes : ethyl acetate $\left.=4: 1\right) .{ }^{1} \mathrm{H}\left(300 \mathrm{MHz}, \mathrm{CDCl}_{3}\right) \delta 1.56(\mathrm{~s}, 6 \mathrm{H}), 2.26(\mathrm{~s}, 1 \mathrm{H})$, 7.29-7.34 (m, $3 \mathrm{H}), 7.45-7.48(\mathrm{~m}, 2 \mathrm{H}) ;{ }^{13} \mathrm{C}\left(75 \mathrm{MHz}, \mathrm{CDCl}_{3}\right)$ : $\delta$ 31.1, 65.7, 67.0, 73.1, 78.7, $86.7,121.5,128.4,129.2,132.5$.

Diyne Alcohol 20b: $\mathrm{R}=1$-adamantyl: Yield was $87 \%$. White solid. $\mathrm{Mp}=150-152{ }^{\circ} \mathrm{C} . \mathrm{R}_{\mathrm{f}}$ $=0.36$ (hexanes : ethyl acetate $=4: 1) .{ }^{1} \mathrm{H}\left(300 \mathrm{MHz}, \mathrm{CDCl}_{3}\right): \delta 1.50(\mathrm{~s}, 6 \mathrm{H}), 1.65-1.66(\mathrm{~m}, 6$ $\mathrm{H}), 1.84-1.85(\mathrm{~m}, 6 \mathrm{H}), 1.93(\mathrm{bs}, 3 \mathrm{H}), 2.05(\mathrm{bs}, 1 \mathrm{H}) ;{ }^{13} \mathrm{C}\left(75 \mathrm{MHz}, \mathrm{CDCl}_{3}\right) \delta$ 27.64, 30.07, $31.13,36.11,42.10,63.14,65.57,67.52,81.08,89.00$; IR (neat) 3353, 2982, 2919, 2851, 2253, 1451, 1362, 1152, 1100, $949 \mathrm{~cm}^{-1}$; mass spectrum (EI) $\mathrm{m} / z$ (\% rel. int.) $242 \mathrm{M}^{+}$(9), 227 (100), 185 (11), 128 (16), 91 (28), calcd. for $\mathrm{C}_{17} \mathrm{H}_{22} \mathrm{O} \mathrm{m} / z$ 242.1671, measd 242.1667. Anal. Calcd. for $\mathrm{C}_{17} \mathrm{H}_{22} \mathrm{O}: \mathrm{C}, 84.25 ; \mathrm{H}, 9.15$. Found: $\mathrm{C}, 84.25 ; \mathrm{H}, 9.22$.

Diyne Alcohol 20c: $\mathrm{R}=$ TBS: Yield was $82 \%$. White solid. $\mathrm{Mp}=80-81{ }^{\circ} \mathrm{C} . \mathrm{R}_{\mathrm{f}}=0.55$ (hexanes : ethyl acetate $=4: 1) .{ }^{1} \mathrm{H}\left(300 \mathrm{MHz} \mathrm{CDCl}_{3}\right) \delta 0.10(\mathrm{~s}, 6 \mathrm{H}), 0.92(\mathrm{~s}, 9 \mathrm{H}), 1.50(\mathrm{~s}, 6$ $\mathrm{H}), 2.02(\mathrm{bs}, 1 \mathrm{H}) ;{ }^{13} \mathrm{C}\left(75 \mathrm{MHz}, \mathrm{CDCl}_{3}\right) \delta-4.88,16.68,25.98,30.97,65.52,67.41,81.32$, 86.39, 87.71; . IR (neat) 3277, 3214, 2953, 2930, 2857, 2231, 2103, 1470, 1462, 1364, 1252, $1165,1096,862,824,777 \mathrm{~cm}^{-1}$; mass spectrum (EI) $\mathrm{m} / z$ (\% rel. int.) $222 \mathrm{M}^{+}$(8), 165 (56), 123 
(100), 107 (27), 84 (47), 75 (30), calcd. for $\mathrm{C}_{13} \mathrm{H}_{22} \mathrm{OSi} \mathrm{m} / \mathrm{z}$ 222.1440, measd 222.1441. Anal. Calcd. for $\mathrm{C}_{13} \mathrm{H}_{22} \mathrm{OSi}$ : C, 70.21; H, 9.97. Found: C, 70.07; H, 10.39

Diyne Alcohol 20d: $\mathrm{R}=$ TIPS: Yield was $72 \%$. White solid. $\mathrm{Mp}=50-51{ }^{\circ} \mathrm{C} . \mathrm{R}_{\mathrm{f}}=0.48$ (hexanes : ethyl acetate $=4: 1) .{ }^{1} \mathrm{H}\left(300 \mathrm{MHz}, \mathrm{CDCl}_{3}\right) \delta 1.05(\mathrm{~s}, 21 \mathrm{H}), 1.51(\mathrm{~s}, 6 \mathrm{H}), 2.09(\mathrm{bs}, 1$ $\mathrm{H}) ;{ }^{13} \mathrm{C}\left(75 \mathrm{MHz}, \mathrm{CDCl}_{3}\right) \delta 11.17,18.47,30.99,65.54,67.68,80.58,84.78,88.79$.

\section{General Procedure for the Synthesis of Diacetylene 21:}

To a solution of the proper diyne alcohol $20(10.8 \mathrm{mmol})$ in benzene $(540 \mathrm{~mL})$, was added powdered $\mathrm{KOH}(1.33 \mathrm{~g}, 24 \mathrm{mmol})$ in one portion. The resulting mixture was heated and refluxed under $\mathrm{N}_{2}$ until the reaction was complete as monitored by TLC. The reaction mixture was cooled to room temperature. Solids were removed by filtration through Celite. After concentration, the product was purified by column chromatograph with pure hexanes.

Diacetylene 21a: $\mathrm{R}=\mathrm{C}_{6} \mathrm{H}_{5}$. Clear colorless liquid. Darken upon exposure to air for short periods. Yield was $65 \%$. $\mathrm{R}_{\mathrm{f}}=0.64$ (hexanes : ethyl acetate $\left.=4: 1\right) .{ }^{1} \mathrm{H}\left(300 \mathrm{MHz}, \mathrm{CDCl}_{3}\right)$ $\delta 2.37(\mathrm{~s}, 1 \mathrm{H}), 7.20-7.42(\mathrm{~m}, 5 \mathrm{H}) ;{ }^{13} \mathrm{C}\left(75 \mathrm{MHz}, \mathrm{CDCl}_{3}\right) \delta$ 68.1, 71.3, 73.5, 75.3, 120.9, 128.4, $129.5,132.7$.

Diacetylene 21b: $\mathrm{R}=1$-adamantyl: Yield was $97 \%$. Off-white solid. $\mathrm{Mp}=104-108{ }^{\circ} \mathrm{C}$ (decompose). $\mathrm{R}_{\mathrm{f}}=0.64$ (hexanes : ethyl acetate $\left.=10: 1\right) .{ }^{1} \mathrm{H}\left(300 \mathrm{MHz}, \mathrm{CDCl}_{3}\right) \delta 1.65-1.66(\mathrm{~m}$, $6 \mathrm{H}), 1.85-1.86(\mathrm{~m}, 6 \mathrm{H}), 1.94(\mathrm{bs}, 3 \mathrm{H}), 2.02(\mathrm{~s}, 1 \mathrm{H}) ;{ }^{13} \mathrm{C}\left(75 \mathrm{MHz}, \mathrm{CDCl}_{3}\right) \delta 27.61,29.88$, 36.10, 41.96, 63.54, 65.71, 68.42, 85.42; IR (neat) 3299, 2909, 2851, 2234, 1451, 1011, $619 \mathrm{~cm}^{-}$

${ }^{1}$; mass spectrum (EI) $m / z$ (\% rel. int.) $184 \mathrm{M}^{+}$(100), 169 (19), 155 (32), 141 (78), 128 (67), 115 (57), 91 (30), calcd. for $\mathrm{C}_{14} \mathrm{H}_{16} \mathrm{~m} / z$ 184.1252, measd 184.1253. Anal. Calcd. for $\mathrm{C}_{14} \mathrm{H}_{16}$ : C, 91.25; H, 8.75. Found: C, 91.06; H, 9.10.

Diacetylene 21d: $\mathrm{R}=$ Tips: Yield was $89 \%$. Clear colorless liquid (turned orange after exposure to air for short periods). $\mathrm{R}_{\mathrm{f}}=0.68$ (hexanes : ethyl acetate $\left.=4: 1\right) .{ }^{1} \mathrm{H}(300 \mathrm{MHz}$, $\left.\mathrm{CDCl}_{3}\right) \delta 1.06(\mathrm{~m}, 21 \mathrm{H}), 2.05(\mathrm{~s}, 1 \mathrm{H}) ;{ }^{13} \mathrm{C}\left(75 \mathrm{MHz}, \mathrm{CDCl}_{3}\right) \delta 11.14,18.45,65.52,68.61$, 82.00, 88.99.

\section{General Procedure for the Conversion of the Diacetylene 21 to the Triacetylene 4:}

To a solution of diacetylene $21(1 \mathrm{mmol})$ in toluene $(2 \mathrm{~mL})$ at $0{ }^{\circ} \mathrm{C}$ were added $\mathrm{CuCl}(0.15 \mathrm{mmol}), \mathrm{NH}_{2} \mathrm{OH} \cdot \mathrm{HCl}(0.3 \mathrm{mmol})$ and $\mathrm{n}-\mathrm{BuNH}_{2}(1.5 \mathrm{mmol})$ in order. Alkynyl bromide 19 (1 mmol) was diluted with $1 \mathrm{~mL}$ toluene and was added dropwise to the mixture. The reaction mixture was allowed to warm to room temperature and stir for 10 to 18 hours. The reaction was quenched with $\mathrm{H}_{2} \mathrm{O}$ and extracted with ether. The organic layer was washed with $\mathrm{H}_{2} \mathrm{O}$, brine and dried with $\mathrm{MgSO}_{4}$. After the solvent was removed by rotovapor, the product was purified by column chromatograph on silica gel with hexanes.

Triyne 4a: $\mathrm{R}=\mathrm{R}^{\prime}=\mathrm{C}_{6} \mathrm{H}_{5}$ : Yield $89 \%$. Yellow crystals which became light green after exposure to visible light. $\mathrm{R}_{\mathrm{f}}=0.53$ (hexanes). $\mathrm{Mp}=89-90{ }^{\circ} \mathrm{C}$, lit. $91-92{ }^{\circ} \mathrm{C} .{ }^{4}{ }^{1} \mathrm{H}(300 \mathrm{MHz}$, $\left.\mathrm{CDCl}_{3}\right) \delta 7.32-7.55(\mathrm{~m}, 10 \mathrm{H}) ;{ }^{13} \mathrm{C}\left(75 \mathrm{MHz} \mathrm{CDCl}_{3}\right) \delta 66.4,74.4,78.5,120.9,128.5,129.7$, 133.0.

Triyne 4b: $\mathrm{R}=\mathrm{R}^{\prime}=1$-adamantyl: Yield $56 \%$. Crystalline white solid. $\mathrm{Mp}=>200{ }^{\circ} \mathrm{C}$ (decompose). $\mathrm{R}_{\mathrm{f}}=0.44$ (hexanes). ${ }^{1} \mathrm{H}\left(300 \mathrm{MHz}, \mathrm{CDCl}_{3}\right) \delta 1.65$ (bs, $\left.12 \mathrm{H}\right), 1.84$ (bs, $\left.12 \mathrm{H}\right)$, 1.93 (bs, $6 \mathrm{H}) ;{ }^{13} \mathrm{C}\left(75 \mathrm{MHz}, \mathrm{CDCl}_{3}\right) \delta 27.61,30.13,36.08,42.02,61.53,64.60,86.57$; IR (neat) $3308,2907,2851,2211,1451,1364,1343,1100,1075,974,907,733 \mathrm{~cm}^{-1}$; mass spectrum (EI) m/z (\% rel. int.) $342 \mathrm{M}^{+}$(100), 202 (10), 165 (17), 147 (11), 135 (9), 129 (65), 115 (19), 91 (42), 
calcd. for $\mathrm{C}_{26} \mathrm{H}_{30} \mathrm{~m} / z$ 342.2348, measd 342.2339. Anal. Calcd. for $\mathrm{C}_{26} \mathrm{H}_{30}:$ C, 91.17; H, 8.83. Found: C, 91.23; H, 9.17.

Triyne 4c: $\mathrm{R}=$ TBS: Yield $78 \%$. White solid, $\mathrm{Mp}=147-149{ }^{\circ} \mathrm{C}$, lit. ${ }^{4} 154-155.5{ }^{\circ} \mathrm{C} . \mathrm{R}_{\mathrm{f}}=$ 0.72 (hexanes). ${ }^{1} \mathrm{H}\left(300 \mathrm{MHz}, \mathrm{CDCl}_{3}\right) \delta 0.11(\mathrm{~s}, 12 \mathrm{H}), 0.92(\mathrm{~s}, 18 \mathrm{H}) ;{ }^{13} \mathrm{C}\left(75 \mathrm{MHz}, \mathrm{CDCl}_{3}\right) \delta$ 4.99, 16.81, 25.98, 61.63, 86.21, 88.52.

Triyne 4d: $\mathrm{R}=$ TIPS: Yield $96 \%$. White solid, $\mathrm{Mp}=140-142{ }^{\circ} \mathrm{C}$, lit. ${ }^{4} 148-149{ }^{\circ} \mathrm{C}$ $(\mathrm{MeOH}) . \mathrm{R}_{\mathrm{f}}=0.75$ (hexanes). ${ }^{1} \mathrm{H}\left(300 \mathrm{MHz}, \mathrm{CDCl}_{3}\right) \delta 1.06(\mathrm{~s}, 42 \mathrm{H}) ;{ }^{13} \mathrm{C}\left(75 \mathrm{MHz}, \mathrm{CDCl}_{3}\right) \delta$ $11.24,18.48,61.32,84.62,89.73$.

\section{Reaction of the cyclohexenyl carbene complex 6 with the diphenyltriyne $4 a$.}

A solution of the phenyl-substituted triyne $4 \mathbf{a}(0.4 \mathrm{~g}, 1.77 \mathrm{mmol})$ and the cyclohexenyl carbene complex $6(1.12 \mathrm{~g}, 3.54 \mathrm{mmol})$ in $35 \mathrm{~mL}$ THF was introduced into a flame-dried $100 \mathrm{~mL}$ pear-shaped flask on which the $14 / 20$ joint had been replaced by a threaded high-vacuum stopcock. The reaction mixture was deoxygenated by the freeze-pump-thaw method (3 cycles). The flask was back-filled with Argon at room temperature and then the flask was sealed with the teflon stopcock. The mixture was heated in an oil bath at $55{ }^{\circ} \mathrm{C}$ for 24 hours. After cooling to room temperature, the solvent was removed with a rotavapor and the residue was dissolved in $\mathrm{CHCl}_{3}$ and stirred at room temperature in air overnight. The residue was loaded onto a silica gel chromatography column and eluted with a gradient of solvents from pure hexanes to a $20: 1$ mixture of hexanes to ethyl acetate. The first product to elute was the mono-benzannulated product $7 \mathbf{a}(0.192 \mathrm{~g}, 0.509 \mathrm{mmol})$ in $29 \%$ yield as a light orange solid. The second product was identified as the bis-benzannulated product 8a and obtained in $32 \%$ yield $(0.301 \mathrm{~g}, 0.568 \mathrm{mmol})$ as a light orange solid. Spectral data for 7a: $\mathrm{Mp}=158-162{ }^{\circ} \mathrm{C} ; \mathrm{R}_{\mathrm{f}}=0.25$ (hexanes : ethyl acetate $=10: 1) ;{ }^{1} \mathrm{H}\left(300 \mathrm{MHz}, \mathrm{CDCl}_{3}\right) \delta 1.79(\mathrm{~m}, 4 \mathrm{H}), 2.70-2.77(\mathrm{~m}, 4 \mathrm{H}), 3.90(\mathrm{~s}, 3 \mathrm{H}), 4.97$ $(\mathrm{s}, 1 \mathrm{H}), 7.29-7.52(\mathrm{~m}, 10 \mathrm{H}) ;{ }^{13} \mathrm{C}\left(75 \mathrm{MHz}, \mathrm{CDCl}_{3}\right) \delta$ 22.1, 23.7, 23.9, 60.9, 74.3, 77.4, 78.7, $81.9,112.0,121.9,127.4,127.8,128.3,128.5,128.9,129.2,130.2,131.7,132.3,134.3,146.3$, 154.9, 1 aliphatic C not located; IR (neat) 3544, 2936, 2863, 1451, 1412, 1312, 1300, 1213, 1061, 756, $689 \mathrm{~cm}^{-1}$; mass spectrum (EI) $\mathrm{m} / z$ (\% rel. int.) $378 \mathrm{M}^{+}$(28), 251 (16), 250 (100), 235 (36), 138 (20), 77 (11), calcd. for $\mathrm{C}_{27} \mathrm{H}_{22} \mathrm{O}_{2} \mathrm{~m} / \mathrm{z}$ 378.1620, measd 378.1620. Anal. Calcd. for $\mathrm{C}_{27} \mathrm{H}_{22} \mathrm{O}_{2}: \mathrm{C}, 85.69 ; \mathrm{H}, 5.86$. Found: C, 85.25; H, 6.14. Spectral data for 8a: $\mathrm{Mp}=218-220{ }^{\circ} \mathrm{C}$; $\mathrm{R}_{\mathrm{f}}=0.18$ (hexanes : ethyl acetate $\left.=10: 1\right) ;{ }^{1} \mathrm{H}\left(300 \mathrm{MHz}, \mathrm{CDCl}_{3}\right) \delta 1.75-1.76(\mathrm{~m}, 8 \mathrm{H}), 2.65-$ $2.69(\mathrm{~m}, 8 \mathrm{H}), 3.45(\mathrm{~s}, 6 \mathrm{H}), 4.84(\mathrm{~s}, 2 \mathrm{H}), 7.26-7.42(\mathrm{~m}, 10 \mathrm{H}) ;{ }^{13} \mathrm{C}\left(125 \mathrm{MHz}, \mathrm{CDCl}_{3}\right) \delta 22.21$, $22.22,23.7,23.8,60.1,91.1,113.6,126.0,126.4,128.0,129.1,130.4,131.3,135.0,146.1$, 153.1; IR (neat) 3523, 2928, 1449, 1406, 1300, 1208, 1051, $1011 \mathrm{~cm}^{-1}$; mass spectrum $\mathrm{m} / z(\%$ rel. int.) $530 \mathrm{M}^{+}$(46), 265 (100), 251 (13), 235 (13), calcd. for $\mathrm{C}_{36} \mathrm{H}_{34} \mathrm{O}_{4} \mathrm{~m} / z$ 530.2457, measd 530.2452. Anal. Calcd. for $\mathrm{C}_{36} \mathrm{H}_{34} \mathrm{O}_{4}$ : C, 81.48; H, 6.46. Found: $\mathrm{C}, 81.47 ; \mathrm{H}, 6.53$.

When the reaction of $\mathbf{6}$ and $\mathbf{4 a}$ was carried out as described above with five equivalents of the carbene complex at $0.2 \mathrm{M}$ in $\mathbf{6}$, the bis-benzannulated product $8 \mathbf{a}$ was obtained in $69 \%$ yield as the only product. When the reaction of $\mathbf{6}$ and $\mathbf{4 a}$ was carried out as described above with five equivalents of the triyne at $0.2 \mathrm{M}$ in 6 the mono-benzannulated product $7 \mathbf{a}$ was obtained in $43 \%$ yield as the only product.
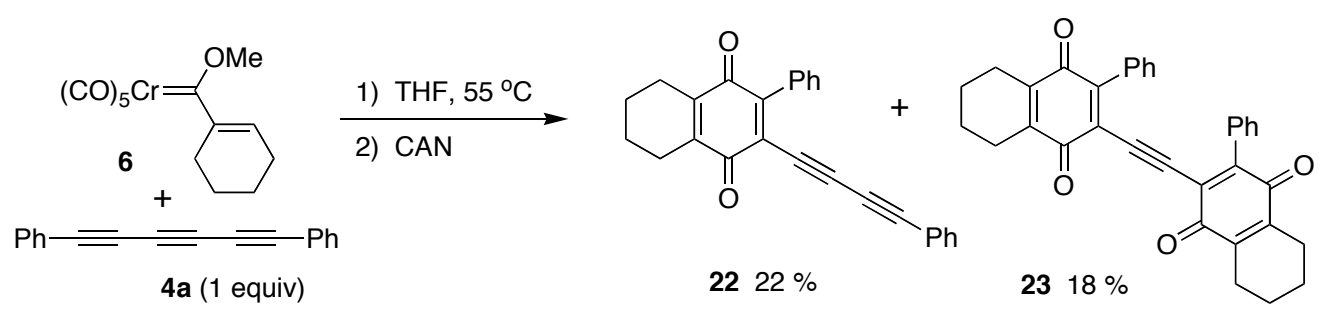
The reaction was also repeated with one equivalent of the triyne at $0.5 \mathrm{M}$ in 6 and the crude reaction mixture was oxidized by stirring with excess aqueous ceric ammonium nitrate at room temperature for $30 \mathrm{~min}$. After concentration, the two quinone products $\mathbf{2 2}$ and $\mathbf{2 3}$ were purified by chromatrography on silica gel. The lack of symmetry of the spectral data of the mono-quinone $\mathbf{2 2}$ demonstrates that the first benzannulation occurs on an end alkyne of the triyne. The symmetry of the spectral data for the bis-quinone $\mathbf{2 3}$ reveals that the second benzannulation occurs by selective reaction of the alkyne unit in 7a that is attached to the phenyl group. Spectral data for 22: $22 \%$ yield; orange solid, $\mathrm{Mp}=169-170{ }^{\circ} \mathrm{C} ; \mathrm{R}_{\mathrm{f}}=0.20$ (hexanes : ethyl acetate $=10: 1) ;{ }^{1} \mathrm{H}\left(300 \mathrm{MHz}, \mathrm{CDCl}_{3}\right) \delta 1.71-1.72(\mathrm{~m}, 4 \mathrm{H}), 2.49-2.51(\mathrm{~m}, 4 \mathrm{H}), 7.30-$ $7.48(\mathrm{~m}, 10 \mathrm{H}) ;{ }^{13} \mathrm{C}\left(75 \mathrm{MHz}, \mathrm{CDCl}_{3}\right) \delta 20.9,21.0,22.9,23.0,73.9,75.1,86.8,88.6,100.3$, $121.1,126.7,127.9,128.5,129.8,130.2,132.2,132.6,142.7,143.4,147.8,183.2$, 185.5; IR (neat) $2938,2203,1645,1443,1354,1302,1279,1227,1161 \mathrm{~cm}^{-1}$; mass spectrum (EI) $\mathrm{m} / \mathrm{z}(\%$ rel. int.) $364 \mathrm{M}^{+}+2$ (100), $362 \mathrm{M}^{+}$(53), 334 (23), 289 (18), 276 (21), 226 (27), 150 (15), 139 (28), 132 (19), 129 (13), 79 (30), calcd. for $\mathrm{C}_{26} \mathrm{H}_{18} \mathrm{O}_{2} \mathrm{~m} / \mathrm{z}$ 362.1307, measd 362.1297. Anal. Calcd. for $\mathrm{C}_{26} \mathrm{H}_{18} \mathrm{O}_{2:} \mathrm{C}, 86.16 ; \mathrm{H}, 5.01$. Found: $\mathrm{C}, 85.75 ; \mathrm{H}, 5.34$. Spectral data for 23: $18 \%$ yield, orange solid, $\mathrm{Mp}>210{ }^{\circ} \mathrm{C}$ (decompose); $\mathrm{R}_{\mathrm{f}}=0.13$ (hexanes : ethyl acetate $\left.=10: 1\right) ;{ }^{1} \mathrm{H}$ $\left(300 \mathrm{MHz} \mathrm{CDCl}_{3}\right) \delta 1.69(\mathrm{~m}, 8 \mathrm{H}), 2.45-2.47(\mathrm{~m}, 8 \mathrm{H}), 7.24-7.32(\mathrm{~m}, 10 \mathrm{H}) ;{ }^{13} \mathrm{C}(75 \mathrm{MHz}$, $\left.\mathrm{CDCl}_{3}\right) \delta 20.9,21.0,22.85,22.91,97.1,126.5,127.6,129.7,130.3,131.9,142.7,143.0,146.5$, 183.0, 185.6; IR (neat) 2938, 1649, 1586, 1343, 1289, $1171 \mathrm{~cm}^{-1} ;$ mass spectrum (EI) $\mathrm{m} / z(\%$ rel. int.) $502 \mathrm{M}^{+}+4$ (100.0), $501 \mathrm{M}^{+}+3$ (20), $500 \mathrm{M}^{+}+2$ (32), $499 \mathrm{M}^{+}+1$ (5), $498 \mathrm{M}^{+}$(4), 251 (44), 69 (11), calcd. for $\mathrm{C}_{34} \mathrm{H}_{26} \mathrm{O}_{4} \mathrm{~m} / z$ 498.1831, measd 498.1825. This compound was also characterized by $\mathrm{X}$-ray diffraction of a single crystal (see appendix).

\section{Reaction of the cyclohexenyl carbene complex 6 with the bis-adamantyltriyne $4 \mathrm{~b}$.}

The benzannulation of triyne $\mathbf{4 b}$ (one equivalent) with carbene complex $\mathbf{6}$ was carried out in THF $(0.05 \mathrm{M}$ in 6$)$ at $55^{\circ} \mathrm{C}$ for $24 \mathrm{~h}$ according to procedure described above for the reaction of $\mathbf{6}$ with $\mathbf{4 a}$. The mono-benzannulated product $\mathbf{7 b}$ was obtained as an off-white solid in $41 \%$ yield along with the bis-benzannulated product $\mathbf{8 b}$ in $23 \%$ yield as a yellow solid. Spectral data for $7 \mathbf{b}: \quad \mathrm{Mp}>220{ }^{\circ} \mathrm{C}$ (decompose), $\mathrm{R}_{\mathrm{f}}=0.44$ (hexanes : ethyl acetate $=4: 1$ ); ${ }^{1} \mathrm{H}$ $\left(300 \mathrm{MHz}, \mathrm{CDCl}_{3}\right) \delta$ 1.67-2.07 (m, $\left.28 \mathrm{H}\right), 2.50-2.51(\mathrm{~m}, 8 \mathrm{H}), 2.66(\mathrm{t}, 2 \mathrm{H}, \mathrm{J}=6 \mathrm{~Hz}), 3.75(\mathrm{~s}, 3$ $\mathrm{H}), 5.12(\mathrm{~s}, 1 \mathrm{H}) ;{ }^{13} \mathrm{C}\left(75 \mathrm{MHz}, \mathrm{CDCl}_{3}\right) \delta 21.80,22.42,23.54,23.79,27.79,29.36,30.47,36.22$, $36.79,40.53,41.62,42.33,60.35,64.61,73.20,84.84,93.46,112.71,127.20,129.43,133.99$, 148.48, 156.81; IR (neat) 3452, 2901, 2851, 1451, 1280, 1192, 1161, 1059.1, 1024, 905, 731 $\mathrm{cm}^{-1}$; mass spectrum (EI) $\mathrm{m} / \mathrm{z}$ (\% rel. int.) $494 \mathrm{M}^{+}$(45), 479 (18), 463 (11), 359 (78), 135 (100), calcd. for $\mathrm{C}_{35} \mathrm{H}_{42} \mathrm{O}_{2} \mathrm{~m} / z$ 494.3185, measd 494.3169. Anal. Calcd. for $\mathrm{C}_{35} \mathrm{H}_{42} \mathrm{O}_{2}: \mathrm{C}, 84.97 ; \mathrm{H}, 8.56$. Found: C, 84.00; H, 9.29. This compound was also characterized by X-ray diffraction of a single crystal (see appendix). Spectral data for 8b: $\mathrm{Mp}=145^{\circ} \mathrm{C}$ (decompose), $\mathrm{R}_{\mathrm{f}}=0.33$ (hexanes : ethyl acetate $=4: 1) ;{ }^{1} \mathrm{H}\left(300 \mathrm{MHz}, \mathrm{CDCl}_{3}\right) \delta 1.64-1.82(\mathrm{~m}, 20 \mathrm{H}), 2.00(\mathrm{bs}, 6 \mathrm{H}), 2.54(\mathrm{t}, 4, \mathrm{H}$, $\mathrm{J}=3.6 \mathrm{~Hz}), 2.60(\mathrm{bs}, 12 \mathrm{H}), 2.70(\mathrm{t}, 4 \mathrm{H}, \mathrm{J}=3.6 \mathrm{~Hz}), 3.72(\mathrm{~s}, 6 \mathrm{H}), 5.18(\mathrm{~s}, 2 \mathrm{H}) ;{ }^{13} \mathrm{C}(75 \mathrm{MHz}$, $\left.\mathrm{CDCl}_{3}\right) \delta 21.92,22.51,22.64,23.71,29.38,36.84,40.45,41.76,58.39,97.42,114.89,125.91$, 129.45, 132.55, 148.48, 155.10; IR (neat) 3611, 3450, 2903, 2851, 1449, 1400, 1321, 1051, 1024, 909, $733 \mathrm{~cm}^{-1}$; mass spectrum (EI) $\mathrm{m} / z$ (\% rel. int.): $646 \mathrm{M}^{+}$(11), 323 (100), 135 (46), calcd. for $\mathrm{C}_{44} \mathrm{H}_{54} \mathrm{O}_{4} m / z$ 646.4022, measd 646.4022. Anal. Calcd. for $\mathrm{C}_{44} \mathrm{H}_{54} \mathrm{O}_{4} \mathrm{C}, 81.69 ; \mathrm{H}, 8.41$. Found: C, 81.12; H, 8.87. 


\section{Reaction of Cyclohexenyl Carbene Complex 6 with the Bis-triisopropylsilyl triyne 4d.}

The benzannulation of triyne $\mathbf{4 d}$ (one equivalent) with carbene complex $\mathbf{6}$ was carried out in toluene $(0.05 \mathrm{M}$ in 6$)$ at $90{ }^{\circ} \mathrm{C}$ for $24 \mathrm{~h}$ according to the procedure described above for the reaction of complex $\mathbf{6}$ with triyne $\mathbf{4 a}$. The product $9 \mathbf{d}$ was purified by silica gel chromatography and was obtained in $81 \%$ yield as an orange oil. The same reaction carried out in THF at $55^{\circ} \mathrm{C}$ gave a $65 \%$ yield. Spectral data for 9d: $R_{\mathrm{f}}=0.6$ (hexanes : ethyl acetate $\left.=10: 1\right) ;{ }^{1} \mathrm{H}(300$ $\left.\mathrm{MHz} \mathrm{CDCl}_{3}\right) \delta$ 1.08-1.13 (m, $\left.42 \mathrm{H}\right), 1.71-1.73(\mathrm{~m}, 4 \mathrm{H}), 2.65-2.69(\mathrm{~m}, 4 \mathrm{H}), 3.80(\mathrm{~s}, 3 \mathrm{H}), 6.01$ $(\mathrm{s}, 1 \mathrm{H}) ;{ }^{13} \mathrm{C}\left(75 \mathrm{MHz}, \mathrm{CDCl}_{3}\right) \delta 11.16,11.34,18.73,21.95,22.07,23.54,23.82,60.38,98.26$, 100.23, 108.56, 101.42, 101.17, 114.66, 125.50, 133.77, 151.70, 153.381 aliphatic C missing; IR (neat): 3502, 2941, 2868, 2132, 1468, 1452, 1408, 1311, 1043, $884 \mathrm{~cm}^{-1}$; mass spectrum (EI) m/z (\% rel. int.) $538 \mathrm{M}^{+}$(25), 454 (18), 453 (55), 168 (18), 154 (19), 141 (16), 87 (33), 73 (59), 59 (100), calcd. for $\mathrm{C}_{33} \mathrm{H}_{54} \mathrm{O}_{2} \mathrm{Si}_{2} \mathrm{~m} / z$ 538.3662, measd 538.3664. Anal, Calcd. for $\mathrm{C}_{33} \mathrm{H}_{54} \mathrm{O}_{2} \mathrm{Si}_{2}: \mathrm{C}$, 73.54; H, 10.10. Found: C, 72.84, H, 10.66.

The regioselectivity of 9d was determined by methylation of the phenol and desilylation. This gave the hydroquinone dimethyl ether 15a which by its symmetry could only have resulted from reaction of complex $\mathbf{6}$ with triyne $\mathbf{4 d}$ at the center alkyne unit.

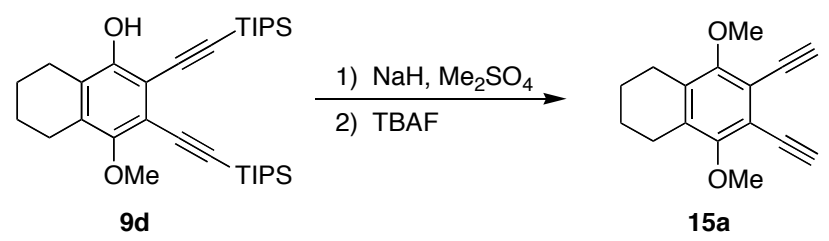

To a solution of compound $9 \mathbf{d}(0.34 \mathrm{~g}, 0.63 \mathrm{mmol})$ in THF $(13 \mathrm{~mL})$ was added $\mathrm{NaH}(50$ $\mathrm{mg}, 60 \%$ dispersion in mineral oil) in one portion. After the bubbles disappeared, $0.12 \mathrm{~mL}$ $\mathrm{Me}_{2} \mathrm{SO}_{4}$ was added. The mixture was stirred at room temperature for 7 hours. The reaction was quenched with sat aq $\mathrm{Na}_{2} \mathrm{CO}_{3}$ and the resulting mixture was stirred at room temperature overnight. The reaction mixture was extracted with ether, the ether layer was washed with $\mathrm{H}_{2} \mathrm{O}$ and brine, and then it was dried with $\mathrm{MgSO}_{4}$. After concentration, the residue was dissolved in 8 $\mathrm{mL}$ THF and then $2.5 \mathrm{~mL}$ of $1 \mathrm{M}$ TBAF in THF was added. The mixture was stirred at room temperature for 1 hour. The reaction was quenched with water and the mixture extracted with ether. The ether layer was washed with $\mathrm{H}_{2} \mathrm{O}$ and brine and the $\mathrm{n}$ dried with $\mathrm{MgSO}_{4}$. The residue was purified by column chromatography on silica gel with a $40: 1$ mixture of hexanes : ethyl acetate to give $0.36 \mathrm{~g}(53 \%)$ of $\mathbf{1 5 a}$ as a white solid. Spectral data for 15a: $\mathrm{R}_{\mathrm{f}}=0.46$ (hexanes : ethyl acetate $=10: 1), \mathrm{Mp}=105-107.5{ }^{\circ} \mathrm{C} ;{ }^{1} \mathrm{H}\left(300 \mathrm{MHz}, \mathrm{CDCl}_{3}\right) \delta 1.70-1.74(\mathrm{~m}, 4 \mathrm{H}), 2.67-$ $2.71(\mathrm{~m}, 4 \mathrm{H}), 3.48(\mathrm{~s}, 2 \mathrm{H}), 3.84(\mathrm{~s}, 6 \mathrm{H}) ;{ }^{13} \mathrm{C}\left(75 \mathrm{MHz}, \mathrm{CDCl}_{3}\right) \delta$ 21.91, 23.76, 60.41, 78.30, 84.57, 116.31, 133.90, 156.10; IR (neat): 3293, 2948, 1458, 1404, 1329, 1090, $1038 \mathrm{~cm}^{-1}$; mass spectrum (EI) $m / z$ (\% rel. int.) $240 \mathrm{M}^{+}$(69), 195 (31), 179 (36), 165 (100), 152 (87), 115 (42), calcd. for $\mathrm{C}_{16} \mathrm{H}_{16} \mathrm{O}_{2} \mathrm{~m} / z$ 240.1150, measd 240.1149. Anal. Calcd. for $\mathrm{C}_{16} \mathrm{H}_{16} \mathrm{O}_{2}: \mathrm{C}, 79.97$; 6.71. Found: C, 79.75; H, 7.16. 


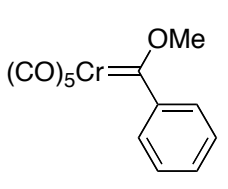

10

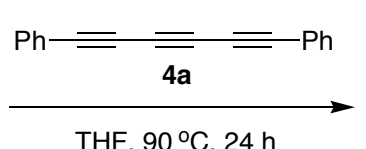

THF, $90^{\circ} \mathrm{C}, 24 \mathrm{~h}$

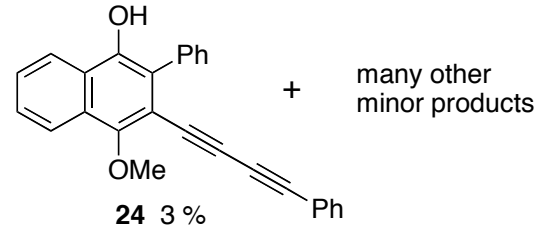

\section{Reaction of the phenyl carbene complex 8 with the diphenyltriyne 4a.}

The benzannulation of triyne $\mathbf{4 a}$ (one equivalent) with carbene complex $\mathbf{1 0}$ was carried out in THF $\left(0.07 \mathrm{M}\right.$ in 10) at $90{ }^{\circ} \mathrm{C}$ for $24 \mathrm{~h}$ according to the procedure described above for the reaction of complex 6 with triyne $4 \mathbf{a}$. The reaction mixture was diluted with $10 \mathrm{~mL} \mathrm{CH}_{2} \mathrm{Cl}_{2}$ and stirred open to air for $12 \mathrm{~h}$. The solution was filtered through a fritted funnel dry packed with Celite 545, concentrated using rotary evaporator. The crude reaction mixture appeared by TLC and ${ }^{1} \mathrm{H}$ NMR to be a complicated mixture of many compounds none of which was estimated (after column chromatography) to have been formed in more thn $8-10 \%$ yield. The crude mixture was loaded onto a silica gel column and elueted with a solvent gradient than ranged from pure hexanes to $5 \%$ ethyl acetate in hexanes. Several fractions were collected but only one compound was obtained in pure form. This compound was tentatively identified as the phenol 24 which was judged to have been formed in $3 \%$ yield based the amount isolated material (5 $\mathrm{mg}$ ) and the weight of additional fractions that contained $\mathbf{2 4}$ along with other compounds. Spectral data for ${ }^{1} \mathrm{H}$ NMR $\left(500 \mathrm{MHz}, \mathrm{CDCl}_{3}\right) \delta 4.15(\mathrm{~s}, 3 \mathrm{H}), 5.41(\mathrm{~s}, 1 \mathrm{H}), 7.12$ - $7.18(\mathrm{~m}, 2 \mathrm{H})$, 7.20 - 7.26 (m, $2 \mathrm{H}), 7.46$ - 7.60 (m, 8 H), 8.14 - 8.16 (m, $1 \mathrm{H}), 8.20$ - 8.25 (m, $1 \mathrm{H})$.

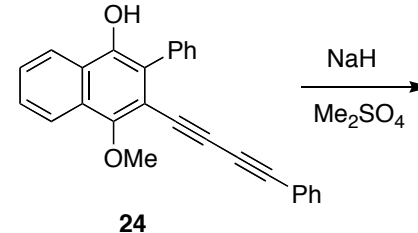

24

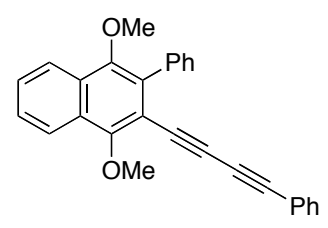

$2596 \%$

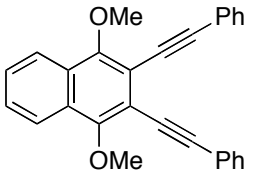

26

not consistent with ${ }^{1} \mathrm{H}$ NMR

In an effort to determine the regioselectivity of $\mathbf{2 4}$, the compound was methylated and the symmetry of the resulting product probed by ${ }^{1} \mathrm{H}$ NMR. A flame dried round bottom flask (5 $\mathrm{mL}$ ) filled with Argon was charged with a solution of $24(5 \mathrm{mg}, 0.013 \mathrm{mmol})$ in $1 \mathrm{~mL}$ THF. Solid $\mathrm{NaH}$ (10 $\mathrm{mg}$ of a $60 \%$ disperson in mineral oil) was then added to the reaction mixture at room temperature. After 5 minutes, dimethylsulfate $(50 \mu \mathrm{L})$ was added and stirring was continued at room temperature for $6 \mathrm{~h}$. The reaction mixture was loaded onto a silica gel column and eluted using (5\%) ethylacetate / hexane to give a $96 \%$ yield of a yellow solid that was tentatively identified as $\mathbf{2 5}$ on the basis of the lack of symmetry in the ${ }^{1} \mathrm{H}$ NMR spectrum. Spectral data for 25: ${ }^{1} \mathrm{H}$ NMR $\left(500 \mathrm{MHz}, \mathrm{CDCl}_{3}\right) \delta 3.51(\mathrm{~s}, 3 \mathrm{H}), 4.18(\mathrm{~s}, 3 \mathrm{H}), 7.17-7.21(\mathrm{~m}, 2$ H), 7.22 - $7.26(\mathrm{~m}, 3 \mathrm{H}), 7.39$ - $7.44(\mathrm{~m}, 1 \mathrm{H}), 7.45$ - $7.51(\mathrm{~m}, 2 \mathrm{H}), 7.53-7.59(\mathrm{~m}, 4 \mathrm{H}), 8.12$ - 8 $.17(\mathrm{~m}, 1 \mathrm{H}), 8.17-8.21(\mathrm{~m}, 1 \mathrm{H})$. 


\section{Reaction of Complex 10 with Triyne 4d.}

The benzannulation of triyne 4d (one equivalent) with carbene complex 10 was carried out in THF $(0.05 \mathrm{M}$ in 10$)$ at $90{ }^{\circ} \mathrm{C}$ for $24 \mathrm{~h}$ according to the general procedure described above for the reaction of carbene complex 6 with triyne $4 \mathbf{a}$. The product was purified by silica gel chromatography to give the furan $11 \mathrm{~d}$ as a yellow oil in $69 \%$ yield. Spectral data for 11d: $R_{\mathrm{f}}=$ 0.69 (hexanes : ethyl acetate $=10: 1) ;{ }^{1} \mathrm{H}\left(300 \mathrm{MHz}, \mathrm{CDCl}_{3}\right) \delta 1.14(\mathrm{~m}, 21 \mathrm{H}), 1.18(\mathrm{~m}, 21 \mathrm{H})$, 4.24 (s, $3 \mathrm{H}), 7.26-7.39(\mathrm{~m}, 4 \mathrm{H}), 8.04-8.07(\mathrm{~m}, 1 \mathrm{H}) ;{ }^{1} \mathrm{H}\left(500 \mathrm{MHz}, \mathrm{C}_{6} \mathrm{D}_{6}\right): \delta 0.80-1.40(\mathrm{~m}, 42$ $\mathrm{H}), 3.59(\mathrm{~s}, 3 \mathrm{H}), 7.03(\mathrm{t}, 1 \mathrm{H}, \mathrm{J}=7.5 \mathrm{~Hz}), 7.20(\mathrm{t}, 2 \mathrm{H}, \mathrm{J}=7.8 \mathrm{~Hz}), 8.16(\mathrm{dd}, 2 \mathrm{H}, \mathrm{J}=1.0,8.6 \mathrm{~Hz})$; ${ }^{13} \mathrm{C}\left(75 \mathrm{MHz}, \mathrm{CDCl}_{3}\right) \delta 11.31,11.34,18.71,18.72,59.32,85.92,94.86,95.98,98.27,98.81$, 106.06, 124.29, 127.57, 128.33, 129.65, 145.63, 161.09; IR (neat): 2946, 2888, 2149, 1605, 1464, 1387, 1161, 1119, 1065, 995, 884, 793, 762, $677 \mathrm{~cm}^{-1}$; mass spectrum (EI) $\mathrm{m} / z(\%$ rel. int.) $534 \mathrm{M}^{+}$(82), 434 (100), 391 (15), 168 (27), 154 (19), 105 (22), 73 (27), 59 (65), calcd. for $\mathrm{C}_{33} \mathrm{H}_{50} \mathrm{O}_{2} \mathrm{Si}_{2} \mathrm{~m} / z$ 534.3349, measd 534.3348;
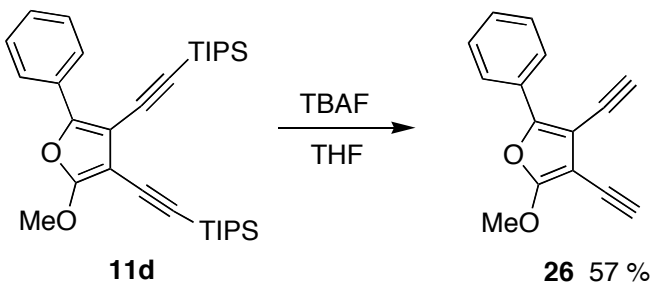

In an effort to determine the regioselectivity of the formation of $\mathbf{1 1 d}$, the triisopropylsilyl groups were removed. To a stirred solution of $11 \mathrm{~d}(86 \mathrm{mg}, 0.159 \mathrm{mmol})$ in $3 \mathrm{~mL}$ THF at $0{ }^{\circ} \mathrm{C}$ was added TBAF $(500 \mu \mathrm{L}, 0.447 \mathrm{mmol}, 1.0 \mathrm{M}$ solution in THF). The reaction mixture was warmed to room temperature and stirring continued at this temperature for $3 \mathrm{~h}$. The reaction mixture was quenched with sat aq ammonium chloride $(1 \times 5 \mathrm{~mL})$ and extracted with ethyl acetate $(3 \times 10 \mathrm{~mL})$. The combined organic layer was dried over $\mathrm{MgSO}_{4}$ and concentrated. The product was purified by silica gel column chromatography (1\% Ethylacetate / Hexane) to give 20 $\mathrm{mg}$ (57\% yield) of a light brown oil that was identified as $\mathbf{2 6}$. The presence of two alkynyl hydrogens is only consistent with structure 26. Spectral data for 26: ${ }^{1} \mathrm{H}$ NMR $(300 \mathrm{MHz}$, $\left.\mathrm{CDCl}_{3}\right) \delta 3.22(\mathrm{~s}, 1 \mathrm{H}), 3.49(\mathrm{~s}, 1 \mathrm{H}), 4.19(\mathrm{~s}, 3 \mathrm{H}), 7.27(\mathrm{tt}, 1 \mathrm{H}, \mathrm{J}=7.5,1.1 \mathrm{~Hz}), 7.35-7.40(\mathrm{~m}, 2$ $\mathrm{H}), 7.90$ - $7.95(\mathrm{~m}, 2 \mathrm{H}) ;{ }^{13} \mathrm{C}$ NMR $\left(75 \mathrm{MHz}, \mathrm{CDCl}_{3}\right) \delta$ 59.0, 73.2, 75.3, 81.4, 84.3, 84.6, 104.6, 124.1, 127.9, 128.5, 129.2, 145.9, 160.8; IR (neat): 3300, 2924, 2856, 2584, 2114, 1728, 1610 $\mathrm{cm}^{-1}$; mass spectrum (FAB) $\mathrm{m} / z$ (\% rel. int.) $222\left(\mathrm{M}^{+}, 100\right), 207$ (16); HRMS (FAB) calcd. for $\mathrm{C}_{15} \mathrm{H}_{10} \mathrm{O}_{2} \mathrm{~m} / z$ 222.0681, measd 222.0678.

\section{Preparation of Diyne 15b:}

To a solution of compound $9 \mathbf{d}(1.25 \mathrm{~g}, 2.32 \mathrm{mmol})$ in $\mathrm{CH}_{2} \mathrm{Cl}_{2}(25 \mathrm{~mL})$ was added 0.28 $\mathrm{mL} \mathrm{Ac}_{2} \mathrm{O}, 0.24 \mathrm{~mL}$ pyridine and $28 \mathrm{mg}$ DMAP in order. The mixture was stirred at room temperature for 18 hours. The reaction was quenched with $\mathrm{H}_{2} \mathrm{O}$ and extracted with $\mathrm{CH}_{2} \mathrm{Cl}_{2}$. The organic layer was washed with $\mathrm{H}_{2} \mathrm{O}$ and brine and then dried with $\mathrm{MgSO}_{4}$. After concentration, the residue was dissolved in $40 \mathrm{~mL}$ THF and then $10 \mathrm{~mL} 1 \mathrm{M}$ TBAF in THF was added. The mixture was stirred at room temperature for 1 hour. The reaction was quenched by water and 
extracted with ether. The ether layer was washed with $\mathrm{H}_{2} \mathrm{O}$ and brine and then dried with $\mathrm{MgSO}_{4}$. After concentration, TLC indicated that some of the acetate ester had been cleaved. Reacetylation was achieved by dissolving the residue in $20 \mathrm{~mL} \mathrm{CH}_{2} \mathrm{Cl}_{2}$ and then by the addition of $0.25 \mathrm{~mL} \mathrm{Ac} \mathrm{O}, 0.21 \mathrm{~mL}$ pyridine and $25 \mathrm{mg}$ DMAP. The mixture was stirred at room temperature for 16 hour. Workup as above and purification of the product on a silica gel column with $10: 1$ of hexanes : ethyl acetate gave $0.36 \mathrm{~g}(58 \%)$ of $\mathbf{1 5 b}$ as a white solid. Spectral data for 15b: $\mathrm{R}_{\mathrm{f}}=0.19$ (hexanes : ethyl acetate $\left.=10: 1\right), \mathrm{Mp}=97.5-99{ }^{\circ} \mathrm{C} ;{ }^{1} \mathrm{H}\left(300 \mathrm{MHz}, \mathrm{CDCl}_{3}\right) \delta$ 1.69-1.74 (m, 4 H), 2.51-2.53 (m, 2 H), 2.68-2.70 (m, 2 H), 2.32 (s, 3 H), 3.40 (s, 1 H), 3.49 (s, 1 $\mathrm{H}), 3.86(\mathrm{~s}, 3 \mathrm{H}) ;{ }^{13} \mathrm{C}\left(75 \mathrm{MHz}, \mathrm{CDCl}_{3}\right) \delta$ 20.59, 21.54, 21.65, 23.68, 23.77, 60.44, 77.21, 77.89, 84.60, 85.07, 116.37, 117.03, 132.91, 133.91, 146.64, 157.59, 168.58; IR (neat): 3287, 2938, 1767, 1412, 1327, 1200, 1028, 424, $\mathrm{cm}^{-1}$; mass spectrum (EI) $\mathrm{m} / z$ (\% rel. int.) $268 \mathrm{M}^{+}(31), 226$ (100), 165 (39), 153 (34), 152 (40), 115 (20), 77 (32), 43 (61), calcd. for $\mathrm{C}_{17} \mathrm{H}_{16} \mathrm{O}_{3} \mathrm{~m} / \mathrm{z}$ 268.1099, measd 268.1101. Anal. Calcd. for $\mathrm{C}_{17} \mathrm{H}_{16} \mathrm{O}_{3}: \mathrm{C}, 76.10 ; \mathrm{H}, 6.01$. Found: C, 76.05; H, 6.12.

\section{Reaction of Diyne 15b with Complex 6 to give 16:}

The benzannulation of diyne 15d (298 mg, $1.11 \mathrm{mmol})$ with carbene complex $\mathbf{6}(736 \mathrm{mg}$, $2.33 \mathrm{mmol}$ ) was carried out in $\mathrm{CH}_{3} \mathrm{CN}(20 \mathrm{~mL}, 0.12 \mathrm{M}$ in 6$)$ at $55^{\circ} \mathrm{C}$ for $24 \mathrm{~h}$ according to the general procedure described above for the reaction of carbene complex $\mathbf{6}$ with triyne $\mathbf{4 a}$. The solvent was removed by rotory evaporator and the residue was dissolved in $\mathrm{CHCl}_{3}$. The mixture was stirred under $500 \mathrm{psi} \mathrm{CO}$ at $40{ }^{\circ} \mathrm{C}$ for 10 hours. Filtration with Celite removed the $\mathrm{Cr}(\mathrm{CO})_{6}$ which had precipitated as a white solid. After concentration, the residue was purified by column chromatography with $10: 1$ of hexanes to ethyl acetate to give $360 \mathrm{mg}$ (67\% yield) of 16 as a white foam. The ${ }^{1} \mathrm{H}$ NMR was complex and presumably due to the formation of two atropisomers which were observed in a $1: 1$ ratio. These isomers were not separated but were taken on as a mixture to the tris-quinone $\mathbf{1 7}$ which does not exist as atropisomers. Spectral data for 16: $\mathrm{R}_{\mathrm{f}}=0.46$ (hexanes : ethyl acetate $=4: 1$ ); $\mathrm{Mp}>210{ }^{\circ} \mathrm{C} ;{ }^{1} \mathrm{H} \mathrm{NMR}\left(\mathrm{CDCl}_{3}\right)$ see spectrum; IR (neat) 3539, 2936, 2859, 2840, 2251, 1757, 1618, 1582, 1452, 1367, 1323, 1229, 1202, 1109, 1055, 910, $733 \mathrm{~cm}^{-1}$; mass spectrum (EI) $\mathrm{m} / z$ (\% rel. int.) $572 \mathrm{M}^{+}(100), 530(91)$, 498 (17), 483 (19), 125 (59); calcd. for $\mathrm{C}_{35} \mathrm{H}_{40} \mathrm{O}_{7} \mathrm{~m} / z$ 572.2774, measd 572.2786. Anal. calcd. for $\mathrm{C}_{35} \mathrm{H}_{40} \mathrm{O}_{7}$ : C, $73.40 ; \mathrm{H}, 7.04$. Found: $\mathrm{C}, 73.50 ; \mathrm{H}, 7.52$.

\section{Preparation of Trisquinone 17:}

To a stirred THF solution of compound $16\left(42 \mathrm{mg}\right.$ in $1.5 \mathrm{~mL}$ THF) at $0{ }^{\circ} \mathrm{C}$ was added $\mathrm{LiAlH}_{4}$ in THF $(1 \mathrm{M}, 0.15 \mathrm{~mL})$. The mixture was stirred at $0{ }^{\circ} \mathrm{C}$ for half an hour. The reaction was quenched with sat. aq $\mathrm{NH}_{4} \mathrm{Cl}$ solution and extracted with ether. The ether layer was washed with $\mathrm{H}_{2} \mathrm{O}$ and brine and then dried with $\mathrm{MgSO}_{4}$. After concentration, the residue was dissolved in $1.5 \mathrm{~mL}$ THF and then aqueous ceric ammonium nitrate $\left(400 \mathrm{mg}\right.$ in $\left.1 \mathrm{~mL} \mathrm{H}_{2} \mathrm{O}\right)$ was added. The mixture was stirred at room temperature for 5 minutes. The reaction was quenched by $\mathrm{H}_{2} \mathrm{O}$ and extracted with ether. The ether layer was washed with $\mathrm{H}_{2} \mathrm{O}$ and brine and then dried with $\mathrm{MgSO}_{4}$. After concentration, the crude product was purified by silica gel column chromatography with 10:1 of hexanes : ethyl acetate to give $20 \mathrm{mg}(57 \%)$ of tris-quinone 17 as a yellow solid $\left(\mathrm{R}_{\mathrm{f}}=0.4\right.$ (hexanes : ethyl acetate $\left.=4: 1\right)$ ). Spectral data for $17:{ }^{1} \mathrm{H}(300 \mathrm{MHz}$, $\left.\mathrm{CDCl}_{3}\right) \delta 1.68-1.70(\mathrm{~m}, 12 \mathrm{H}), 2.39-2.43(\mathrm{~m}, 12 \mathrm{H}), 6.35(\mathrm{~s}, 2 \mathrm{H}) ;{ }^{13} \mathrm{C}\left(75 \mathrm{MHz}, \mathrm{CDCl}_{3}\right) \delta 20.76$, $20.87,22.41,22.52,22.68,22.81,134.43,139.37,142.86,143.07,143.14,145.85,183.22$, 184.32, 186.09; IR (neat): 2940, 2863, 1651, 1428, 1287, 1264, 1229, 914, $731 \mathrm{~cm}^{-1}$; mass spectrum (EI) $m / z$ (\% rel. int.) $486 \mathrm{M}^{+}+4$ (3), $485 \mathrm{M}^{+}+3$ (9), $484 \mathrm{M}+2$ (21), $483 \mathrm{M}^{+}+1$ (11), 
$482 \mathrm{M}^{+}$(24), 165 (11), 152 (12), 129 (13), 107 (23), 105 (37), 79 (100), 81 (22), 80 (23), 78 (24), 77 (70), 44 (34), 43 (76), 41 (22); HRMS (EI) calcd. for $\mathrm{C}_{30} \mathrm{H}_{26} \mathrm{O}_{6} \mathrm{~m} / z$ 482.1729, measd 482.1732 .

References:

1) Fomina, L.; Fomine, S.; Ogawa, T., Polym. Bull., 1995, 34, 547.

2) Hofmeister, H.; Annen, K.; Laurent, H.; Wiechert, R., Angew. Chem. Int. Ed., 1984, $23,727$.

3) Volkov, A. N.; Skvortsov, Y. M.; Danda, I. I.; Shostakovskii, M. F., J. Org. Chem., USSR, 1970, 6, 903.

4) Rubin, Y.; Lin, S. S.; Knobler, C. B.; Anthony, J.; Boldi, A. M.; Diederich, F.; J. Am. Chem. Soc., 1991, 113, 6943. 


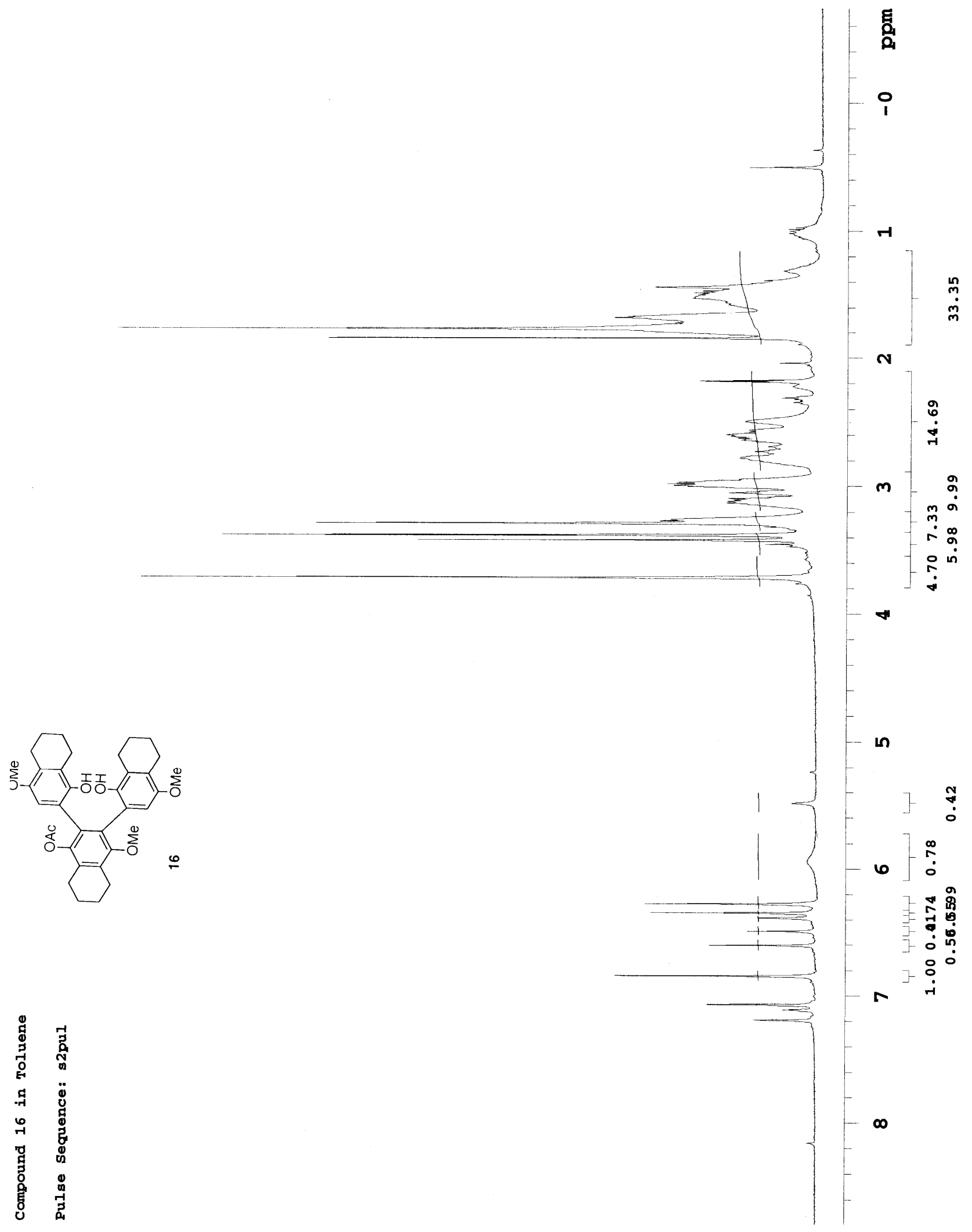




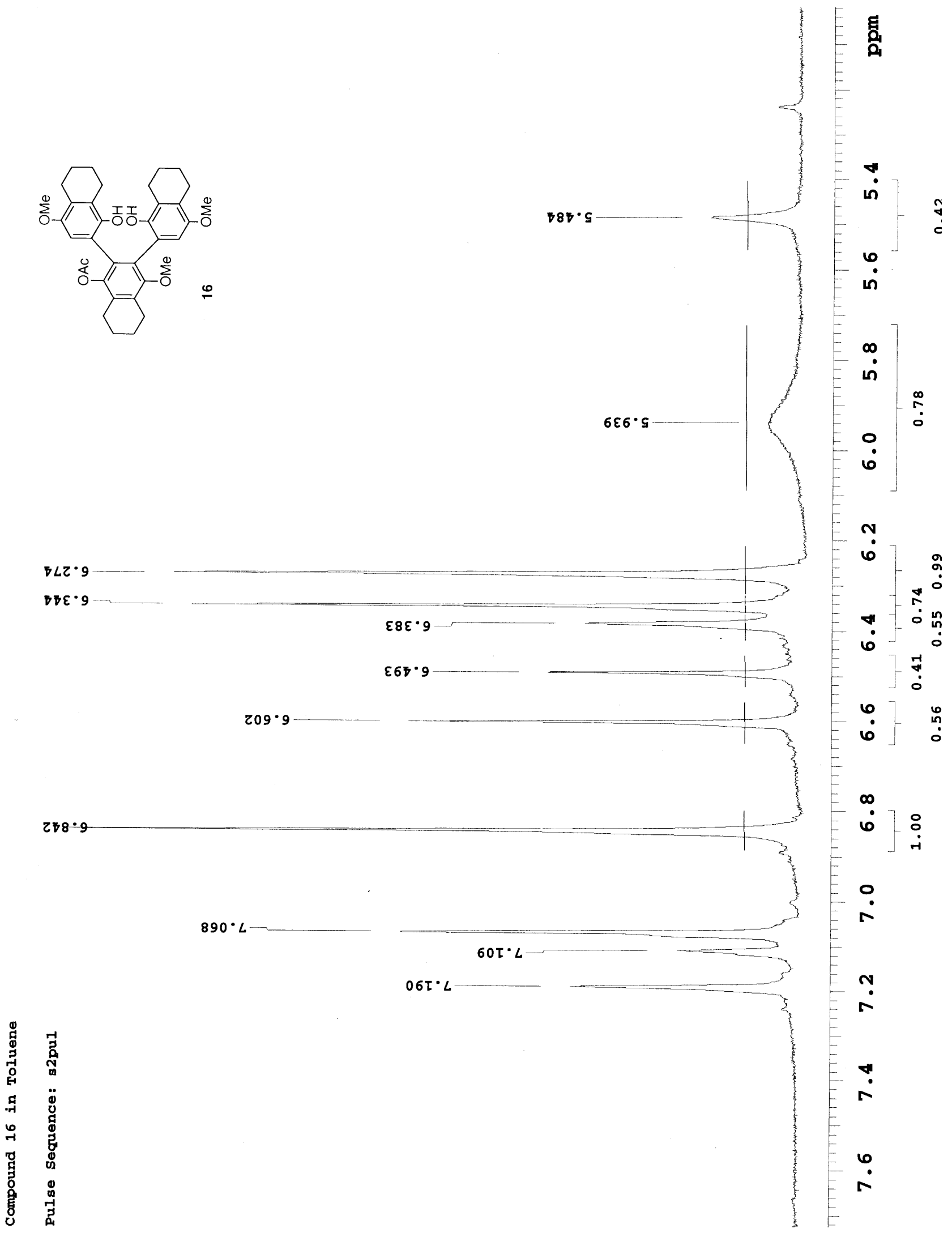




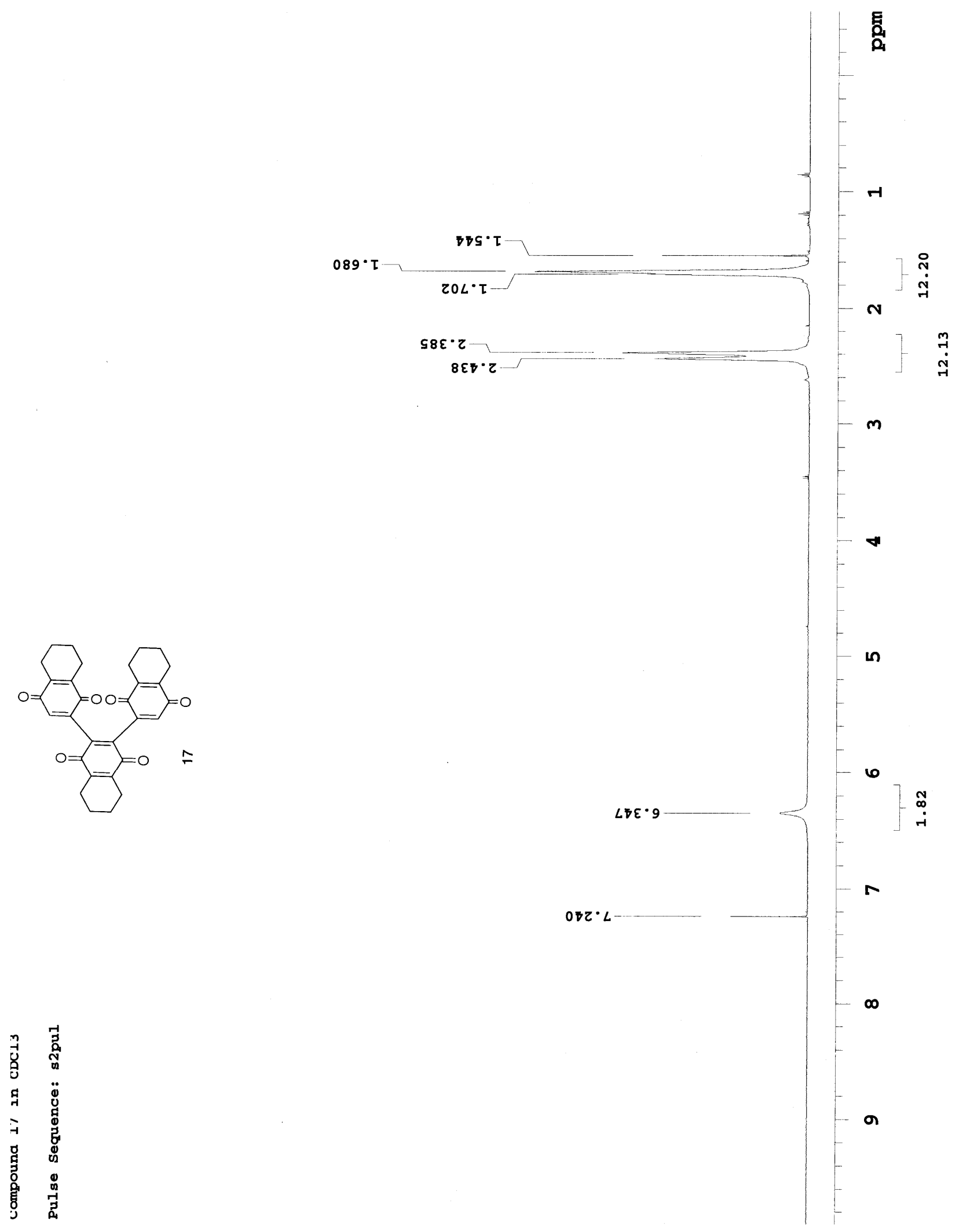




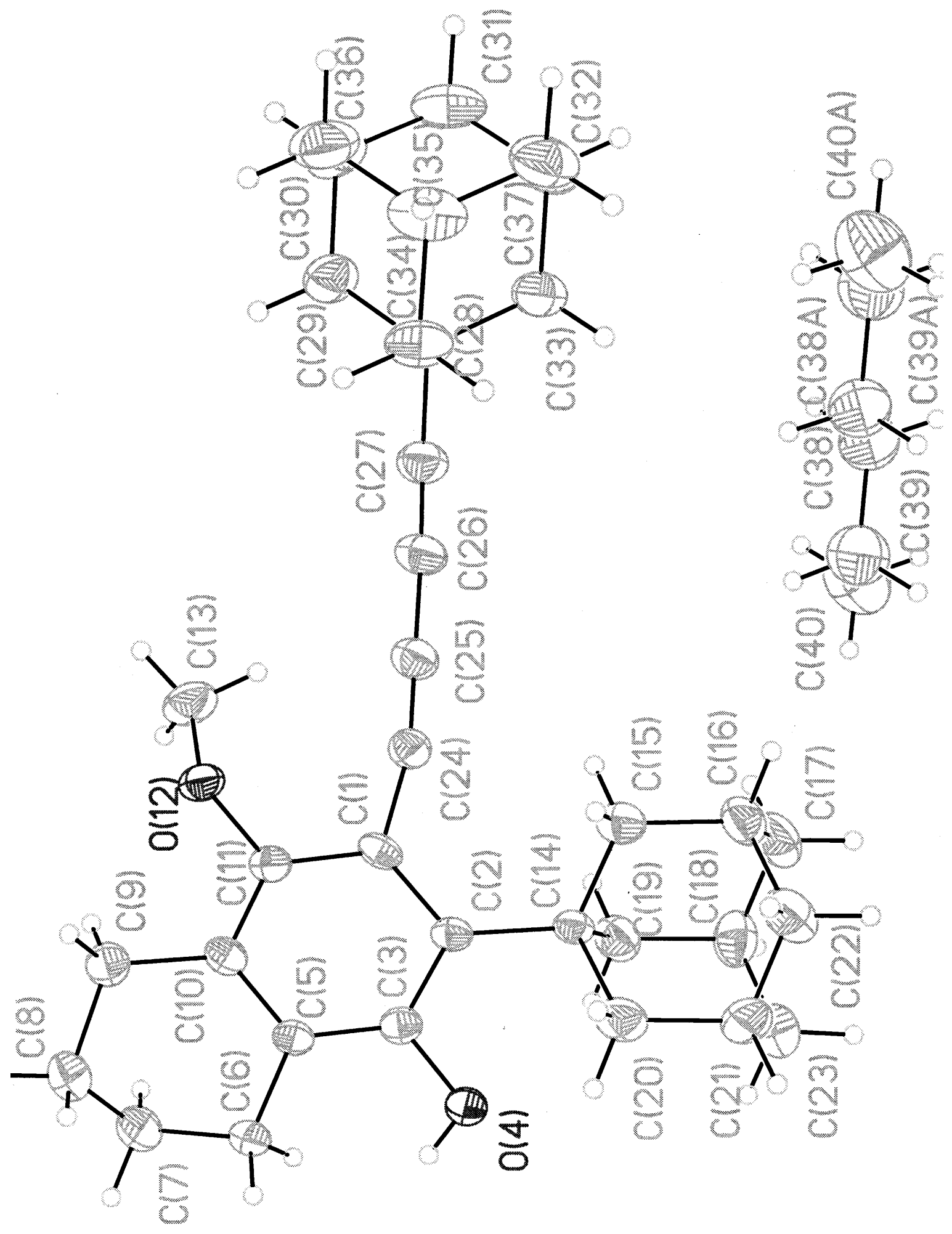

ORTEP Drawing for Phenol 7b. 
Table A.1.1. Crystal data and structure refinement for $\mathbf{7 b}$

\begin{tabular}{|c|c|}
\hline Identification code & compound $7 \mathrm{~b}$ \\
\hline Empirical formula & C38 H49 O2 \\
\hline Formula weight & 537.77 \\
\hline Temperature & $173(2) \quad K$ \\
\hline Wavelength & $0.71073 \AA$ \\
\hline Crystal system & Monoclinic \\
\hline Space group & $\mathrm{P} 21 / \mathrm{n}$ \\
\hline Unit cell dimensions & $\begin{array}{l}\mathrm{a}=13.110(3) \AA \\
\mathrm{b}=12.268(3) \AA \\
\mathrm{c}=19.150(4) \AA \\
\mathrm{a} \text { lpha }=90 \mathrm{deg} . \\
\text { beta }=100.39(3) \text { deg. } \\
\text { gamma }=90 \mathrm{deg} .\end{array}$ \\
\hline Volume & $3029.3(11) \AA^{3}$ \\
\hline $\begin{array}{l}\text { Z } \\
\text { Density (calculated) }\end{array}$ & $\begin{array}{l}6 \\
1.179 \mathrm{Mg} / \mathrm{m}^{3}\end{array}$ \\
\hline Absorption coefficient & $0.070 \mathrm{~mm}^{-1}$ \\
\hline$F(000)$ & 1172 \\
\hline Crystal size & $0.1 \times 0.15 \times 0.6 \mathrm{~mm}$ \\
\hline Theta range for data collection & 1.75 to 28.45 deg. \\
\hline Index ranges & $-17<=\mathrm{h}<=17, \quad-16<=\mathrm{k}<=16, \quad-25<=1<=24$ \\
\hline Reflections collected / unique & $31737 / 7436[R($ int $)=0.1234]$ \\
\hline Completeness to theta $=28.45$ & $97.1 \%$ \\
\hline Refinement method & Full-matrix least-squares on $\mathrm{F}^{2}$ \\
\hline Data / restraints / parameters & $7436 / 0 / 365$ \\
\hline Goodness-of-fit on $\mathrm{F}^{\wedge} 2$ & 1.045 \\
\hline Final R indices [I>2sigma(I)] & $\mathrm{R} 1=0.0784, \mathrm{wR} 2=0.1828$ \\
\hline R indices (all data) & $\mathrm{R} 1=0.1957, \mathrm{wR} 2=0.2259$ \\
\hline Largest diff. peak and hole & 0.545 and $-0.421{\mathrm{e} . \mathrm{A}^{-3}}^{-0.4}$ \\
\hline
\end{tabular}


Table A.1.2. Atomic coordinates ( $\left.\mathrm{x} 10^{4}\right)$, equivalent isotropic displacement parameters $\left(\AA^{2} \times 10^{3}\right)$, and occupancies for $\mathbf{7 b}$

\begin{tabular}{|c|c|c|c|c|c|}
\hline & $x$ & y & z & $\mathrm{U}(\mathrm{eq})$ & Occ. \\
\hline$C(1)$ & $3951(2)$ & $537(2)$ & $3259(1)$ & $24(1)$ & 1 \\
\hline$C(2)$ & $4151(2)$ & $1410(2)$ & $2817(1)$ & $23(1)$ & 1 \\
\hline$C(3)$ & $3253(2)$ & $1960(2)$ & $2480(2)$ & $26(1)$ & 1 \\
\hline$O(4)$ & $3409(2)$ & $2803(2)$ & $2038(1)$ & $33(1)$ & 1 \\
\hline$C(5)$ & $2253(2)$ & $1710(2)$ & $2562(1)$ & $24(1)$ & 1 \\
\hline$C(6)$ & $1346(2)$ & $2350(3)$ & $2163(2)$ & $31(1)$ & 1 \\
\hline$C(7)$ & $350(2)$ & 2171 (3) & $2443(2)$ & $44(1)$ & 1 \\
\hline$C(8)$ & $169(3)$ & $1002(3)$ & $2560(2)$ & $47(1)$ & 1 \\
\hline$C(9)$ & $1023(2)$ & $534(2)$ & $3114(2)$ & $34(1)$ & 1 \\
\hline$C(10)$ & $2090(2)$ & $853(2)$ & $3002(2)$ & $25(1)$ & 1 \\
\hline $\mathrm{C}(11)$ & $2945(2)$ & $288(2)$ & $3342(2)$ & $25(1)$ & 1 \\
\hline$O(12)$ & $2781(2)$ & $-605(2)$ & $3749(1)$ & $30(1)$ & 1 \\
\hline$C(13)$ & $2906(3)$ & $-398(3)$ & $4499(2)$ & $43(1)$ & 1 \\
\hline$C(14)$ & $5230(2)$ & $1757(2)$ & $2705(1)$ & $24(1)$ & 1 \\
\hline C (15) & $6135(2)$ & $1059(3)$ & $3077(2)$ & $37(1)$ & 1 \\
\hline$C(16)$ & $7184(2)$ & $1443(3)$ & $2947(2)$ & $40(1)$ & 1 \\
\hline$C(17)$ & $7343(3)$ & $2636(3)$ & $3197(2)$ & $50(1)$ & 1 \\
\hline$C(18)$ & $6497(3)$ & $3332(3)$ & $2822(2)$ & $45(1)$ & 1 \\
\hline$C(19)$ & $5453(2)$ & $2929(3)$ & $2966(2)$ & $39(1)$ & 1 \\
\hline$C(20)$ & $5292(2)$ & $1697(3)$ & $1903(2)$ & $40(1)$ & 1 \\
\hline$C(21)$ & $6335(3)$ & $2136(3)$ & $1766(2)$ & $47(1)$ & 1 \\
\hline$C(22)$ & $7183(3)$ & $1426(3)$ & $2147(2)$ & $49(1)$ & 1 \\
\hline$C(23)$ & $6476(3)$ & $3304(3)$ & $2036(2)$ & $50(1)$ & 1 \\
\hline$C(24)$ & $4711(2)$ & $-189(2)$ & $3638(2)$ & $28(1)$ & 1 \\
\hline$C(25)$ & $5192(2)$ & $-890(2)$ & $3985(2)$ & $32(1)$ & 1 \\
\hline$C(26)$ & $5744(2)$ & $-1717(3)$ & $4360(2)$ & $35(1)$ & 1 \\
\hline$C(27)$ & $6190(2)$ & $-2459(3)$ & $4679(2)$ & $35(1)$ & 1 \\
\hline $\mathrm{C}(28)$ & $6759(2)$ & $-3367(2)$ & $5060(2)$ & $30(1)$ & 1 \\
\hline$C(29)$ & $6252(3)$ & $-3721(3)$ & $5683(2)$ & $42(1)$ & 1 \\
\hline$C(30)$ & $6865(3)$ & $-4669(3)$ & $6075(2)$ & $48(1)$ & 1 \\
\hline $\mathrm{C}(31)$ & $7958(3)$ & $-4296(3)$ & $6356(2)$ & $52(1)$ & 1 \\
\hline$C(32)$ & $8475(3)$ & $-3949(3)$ & $5751(2)$ & $46(1)$ & 1 \\
\hline C (33) & $7873(3)$ & $-3005(3)$ & $5358(2)$ & $41(1)$ & 1 \\
\hline$C(34)$ & $6776(3)$ & $-4324(3)$ & $4563(2)$ & $41(1)$ & 1 \\
\hline$C(35)$ & $7395(3)$ & $-5261(3)$ & $4958(2)$ & $49(1)$ & 1 \\
\hline$C(36)$ & $6874(3)$ & $-5615(3)$ & $5574(2)$ & $55(1)$ & 1 \\
\hline$C(37)$ & $8488(3)$ & $-4889(3)$ & $5248(2)$ & $52(1)$ & 1 \\
\hline $\mathrm{C}(38)$ & $9986(3)$ & $569(3)$ & $5137(2)$ & $70(1)$ & 1 \\
\hline$C(39)$ & $9376(3)$ & $1351(4)$ & $4637(2)$ & $72(1)$ & 1 \\
\hline$C(40)$ & $9276(4)$ & $2440(4)$ & $4952(3)$ & $81(2)$ & 1 \\
\hline
\end{tabular}

$\mathrm{U}(\mathrm{eq})$ is defined as one third of the trace of the orthogonalized Uij tensor. 
Table A.1.3. Bond lengths [A] and angles [deg] for $\mathbf{7 b}$

\begin{tabular}{|c|c|}
\hline$C(1)-C(11)$ & $1.391(4)$ \\
\hline$C(1)-C(2)$ & $1.418(4)$ \\
\hline$C(1)-C(24)$ & $1.432(4)$ \\
\hline$C(2)-C(3)$ & $1.408(4)$ \\
\hline$C(2)-C(14)$ & $1.529(4)$ \\
\hline$C(3)-O(4)$ & $1.375(3)$ \\
\hline$C(3)-C(5)$ & $1.383(4)$ \\
\hline$C(5)-C(10)$ & $1.388(4)$ \\
\hline$C(5)-C(6)$ & $1.512(4)$ \\
\hline$C(6)-C(7)$ & $1.514(4)$ \\
\hline$C(7)-C(8)$ & $1.478(5)$ \\
\hline$C(8)-C(9)$ & $1.510(4)$ \\
\hline$C(9)-C(10)$ & $1.504(4)$ \\
\hline$C(10)-C(11)$ & $1.378(4)$ \\
\hline $\mathrm{C}(11)-\mathrm{O}(12)$ & $1.384(3)$ \\
\hline $\mathrm{O}(12)-\mathrm{C}(13)$ & $1.439(3)$ \\
\hline$C(14)-C(15)$ & $1.531(4)$ \\
\hline C (14) -C (19) & $1.532(4)$ \\
\hline$C(14)-C(20)$ & $1.555(4)$ \\
\hline$C(15)-C(16)$ & $1.516(4)$ \\
\hline$C(16)-C(22)$ & $1.532(5)$ \\
\hline$C(16)-C(17)$ & $1.543(5)$ \\
\hline$C(17)-C(18)$ & $1.479(5)$ \\
\hline$C(18)-C(23)$ & $1.499(5)$ \\
\hline C (18)-C (19) & $1.528(4)$ \\
\hline$C(20)-C(21)$ & $1.534(5)$ \\
\hline$C(21)-C(22)$ & $1.495(5)$ \\
\hline$C(21)-C(23)$ & $1.524(5)$ \\
\hline$C(24)-C(25)$ & $1.194(4)$ \\
\hline$C(25)-C(26)$ & $1.372(4)$ \\
\hline$C(26)-C(27)$ & $1.189(4)$ \\
\hline$C(27)-C(28)$ & $1.461(4)$ \\
\hline$C(28)-C(34)$ & $1.514(4)$ \\
\hline$C(28)-C(29)$ & $1.529(4)$ \\
\hline$C(28)-C(33)$ & $1.535(4)$ \\
\hline$C(29)-C(30)$ & $1.531(5)$ \\
\hline$C(30)-C(31)$ & $1.508(5)$ \\
\hline$C(30)-C(36)$ & $1.508(5)$ \\
\hline C (31) -C (32) & $1.506(5)$ \\
\hline$C(32)-C(37)$ & $1.504(5)$ \\
\hline$C(32)-C(33)$ & $1.522(4)$ \\
\hline$C(34)-C(35)$ & $1.526(4)$ \\
\hline$C(35)-C(37)$ & $1.511(5)$ \\
\hline$C(35)-C(36)$ & $1.529(5)$ \\
\hline$C(38)-C(39)$ & $1.482(5)$ \\
\hline $\mathrm{C}(38)-\mathrm{C}(38) \# 1$ & $1.495(8)$ \\
\hline$C(39)-C(40)$ & $1.481(6)$ \\
\hline$C(11)-C(1)-C(2)$ & $121.0(2)$ \\
\hline$C(11)-C(1)-C(24)$ & $113.1(3)$ \\
\hline$C(2)-C(1)-C(24)$ & $125.9(3)$ \\
\hline$C(3)-C(2)-C(1)$ & $113.9(3)$ \\
\hline$C(3)-C(2)-C(14)$ & $121.4(2)$ \\
\hline
\end{tabular}




\begin{tabular}{|c|c|}
\hline$C(1)-C(2)-C(14)$ & $124.7(2)$ \\
\hline$O(4)-C(3)-C(5)$ & $119.1(2)$ \\
\hline$O(4)-C(3)-C(2)$ & $115.9(3)$ \\
\hline$C(5)-C(3)-C(2)$ & $125.0(3)$ \\
\hline$C(3)-C(5)-C(10)$ & $119.3(3)$ \\
\hline$C(3)-C(5)-C(6)$ & $120.2(3)$ \\
\hline$C(10)-C(5)-C(6)$ & $120.5(3)$ \\
\hline$C(5)-C(6)-C(7)$ & $113.3(3)$ \\
\hline$C(8)-C(7)-C(6)$ & $111.5(3)$ \\
\hline$C(7)-C(8)-C(9)$ & $110.9(3)$ \\
\hline$C(10)-C(9)-C(8)$ & $113.1(3)$ \\
\hline$C(11)-C(10)-C(5)$ & $117.8(3)$ \\
\hline$C(11)-C(10)-C(9)$ & $120.0(3)$ \\
\hline$C(5)-C(10)-C(9)$ & $122.1(2)$ \\
\hline $\mathrm{C}(10)-\mathrm{C}(11)-\mathrm{O}(12)$ & $117.9(3)$ \\
\hline$C(10)-C(11)-C(1)$ & $122.9(3)$ \\
\hline $\mathrm{O}(12)-\mathrm{C}(11)-\mathrm{C}(1)$ & $119.1(2)$ \\
\hline$C(11)-O(12)-C(13)$ & $114.9(2)$ \\
\hline$C(2)-C(14)-C(15)$ & $116.0(2)$ \\
\hline$C(2)-C(14)-C(19)$ & $110.0(2)$ \\
\hline$C(15)-C(14)-C(19)$ & $106.7(2)$ \\
\hline$C(2)-C(14)-C(20)$ & $109.9(2)$ \\
\hline$C(15)-C(14)-C(20)$ & $105.0(2)$ \\
\hline$C(19)-C(14)-C(20)$ & $109.0(2)$ \\
\hline$C(16)-C(15)-C(14)$ & $113.6(3)$ \\
\hline$C(15)-C(16)-C(22)$ & $108.8(3)$ \\
\hline$C(15)-C(16)-C(17)$ & $108.6(3)$ \\
\hline$C(22)-C(16)-C(17)$ & $107.4(3)$ \\
\hline$C(18)-C(17)-C(16)$ & $110.5(3)$ \\
\hline$C(17)-C(18)-C(23)$ & $110.6(3)$ \\
\hline$C(17)-C(18)-C(19)$ & $110.0(3)$ \\
\hline$C(23)-C(18)-C(19)$ & $108.6(3)$ \\
\hline $\mathrm{C}(18)-\mathrm{C}(19)-\mathrm{C}(14)$ & $111.7(3)$ \\
\hline$C(21)-C(20)-C(14)$ & $111.0(3)$ \\
\hline$C(22)-C(21)-C(23)$ & $110.3(3)$ \\
\hline$C(22)-C(21)-C(20)$ & $108.7(3)$ \\
\hline$C(23)-C(21)-C(20)$ & $109.3(3)$ \\
\hline$C(21)-C(22)-C(16)$ & $110.3(3)$ \\
\hline$C(18)-C(23)-C(21)$ & $109.9(3)$ \\
\hline$C(25)-C(24)-C(1)$ & $168.1(3)$ \\
\hline$C(24)-C(25)-C(26)$ & $177.8(3)$ \\
\hline$C(27)-C(26)-C(25)$ & $177.4(3)$ \\
\hline$C(26)-C(27)-C(28)$ & $178.5(4)$ \\
\hline$C(27)-C(28)-C(34)$ & $110.0(2)$ \\
\hline$C(27)-C(28)-C(29)$ & $110.6(3)$ \\
\hline$C(34)-C(28)-C(29)$ & $109.1(3)$ \\
\hline$C(27)-C(28)-C(33)$ & $109.3(3)$ \\
\hline$C(34)-C(28)-C(33)$ & $109.7(3)$ \\
\hline$C(29)-C(28)-C(33)$ & $108.1(3)$ \\
\hline$C(28)-C(29)-C(30)$ & $109.6(3)$ \\
\hline$C(31)-C(30)-C(36)$ & $110.1(3)$ \\
\hline$C(31)-C(30)-C(29)$ & $109.0(3)$ \\
\hline$C(36)-C(30)-C(29)$ & $109.7(3)$ \\
\hline$C(32)-C(31)-C(30)$ & $110.0(3)$ \\
\hline$C(37)-C(32)-C(31)$ & $109.6(3)$ \\
\hline$C(37)-C(32)-C(33)$ & $109.4(3)$ \\
\hline$C(31)-C(32)-C(33)$ & $109.3(3)$ \\
\hline
\end{tabular}




$\begin{array}{ll}C(32)-C(33)-C(28) & 109.7(3) \\ C(28)-C(34)-C(35) & 109.9(3) \\ C(37)-C(35)-C(34) & 109.8(3) \\ C(37)-C(35)-C(36) & 109.1(3) \\ C(34)-C(35)-C(36) & 108.9(3) \\ C(30)-C(36)-C(35) & 109.2(3) \\ C(32)-C(37)-C(35) & 110.3(3) \\ C(39)-C(38)-C(38) \# 1 & 115.0(4) \\ C(40)-C(39)-C(38) & 113.4(4)\end{array}$

Symmetry transformations used to generate equivalent atoms:

$\# 1-x+2,-y,-z+1$ 
Table A.1.4. Anisotropic displacement parameters $\left(\AA^{2} \times 10^{3}\right)$ for $\mathbf{7 b}$

\begin{tabular}{|c|c|c|c|c|c|c|}
\hline & $\mathrm{U} 11$ & $\mathrm{U} 22$ & U33 & U23 & U13 & $\mathrm{U} 12$ \\
\hline C (1) & $24(2)$ & $26(2)$ & $21(2)$ & $-6(1)$ & $-4(1)$ & $2(1)$ \\
\hline C (2) & $26(2)$ & $23(2)$ & $19(2)$ & $-1(1)$ & $0(1)$ & $0(1)$ \\
\hline$C(3)$ & $29(2)$ & $24(2)$ & $23(2)$ & $-1(1)$ & $3(1)$ & $1(1)$ \\
\hline$O(4)$ & $26(1)$ & $36(1)$ & $38(1)$ & $14(1)$ & $4(1)$ & $6(1)$ \\
\hline C (5) & $26(2)$ & $24(2)$ & $20(2)$ & $-2(1)$ & $1(1)$ & $2(1)$ \\
\hline$C(6)$ & $25(2)$ & $38(2)$ & $27(2)$ & $6(1)$ & $0(1)$ & $3(1)$ \\
\hline$C(7)$ & $27(2)$ & $51(2)$ & $53(2)$ & $15(2)$ & $4(2)$ & $8(2)$ \\
\hline C ( 8$)$ & $29(2)$ & $56(2)$ & $54(2)$ & $12(2)$ & $4(2)$ & $-1(2)$ \\
\hline$C(9)$ & $32(2)$ & $30(2)$ & $38(2)$ & $4(1)$ & $5(2)$ & $1(1)$ \\
\hline C (10) & $26(2)$ & $26(2)$ & $22(2)$ & $-6(1)$ & $0(1)$ & $1(1)$ \\
\hline C (11) & $29(2)$ & $20(2)$ & $23(2)$ & $0(1)$ & $0(1)$ & $-2(1)$ \\
\hline$O(12)$ & $37(1)$ & $29(1)$ & $23(1)$ & $4(1)$ & $-1(1)$ & $-5(1)$ \\
\hline C (13) & $57(2)$ & $50(2)$ & $22(2)$ & $3(2)$ & $4(2)$ & $-7(2)$ \\
\hline C (14) & $24(2)$ & $29(2)$ & $18(2)$ & $0(1)$ & $1(1)$ & $3(1)$ \\
\hline$C(15)$ & $36(2)$ & $43(2)$ & $30(2)$ & $4(2)$ & $2(1)$ & $2(2)$ \\
\hline$C(16)$ & $26(2)$ & $54(2)$ & $38(2)$ & $-1(2)$ & $6(2)$ & $6(2)$ \\
\hline C (17) & $32(2)$ & 77 (3) & $38(2)$ & $-14(2)$ & $0(2)$ & $-5(2)$ \\
\hline$C(18)$ & $40(2)$ & $40(2)$ & $58(2)$ & $0(2)$ & $14(2)$ & $-8(2)$ \\
\hline C (19) & $33(2)$ & $44(2)$ & $37(2)$ & $-2(2)$ & $2(2)$ & $-2(2)$ \\
\hline$C(20)$ & $37(2)$ & $57(2)$ & $24(2)$ & $-3(2)$ & $1(1)$ & $4(2)$ \\
\hline C (21) & $43(2)$ & $73(3)$ & $26(2)$ & $8(2)$ & $13(2)$ & $8(2)$ \\
\hline C (22) & $34(2)$ & $72(3)$ & $37(2)$ & $-10(2)$ & $2(2)$ & $8(2)$ \\
\hline C (23) & $34(2)$ & $61(3)$ & $55(2)$ & $7(2)$ & $10(2)$ & $2(2)$ \\
\hline C (24) & $29(2)$ & $29(2)$ & $24(2)$ & $-1(1)$ & $0(1)$ & $-5(1)$ \\
\hline C (25) & $31(2)$ & $31(2)$ & $32(2)$ & $1(2)$ & $-2(1)$ & $0(1)$ \\
\hline$C(26)$ & $35(2)$ & $36(2)$ & $30(2)$ & $3(2)$ & $-4(1)$ & $2(2)$ \\
\hline C (27) & $36(2)$ & $38(2)$ & $28(2)$ & $4(2)$ & $0(1)$ & $1(2)$ \\
\hline C (28) & $33(2)$ & $34(2)$ & $21(2)$ & $6(1)$ & $3(1)$ & $8(1)$ \\
\hline C (29) & $44(2)$ & $52(2)$ & $32(2)$ & $8(2)$ & $13(2)$ & $7(2)$ \\
\hline$C(30)$ & $59(2)$ & $56(2)$ & $32(2)$ & $16(2)$ & $14(2)$ & $3(2)$ \\
\hline C (31) & $69(3)$ & $51(2)$ & $29(2)$ & $5(2)$ & $-7(2)$ & $13(2)$ \\
\hline$C(32)$ & $39(2)$ & $51(2)$ & $42(2)$ & $4(2)$ & $-7(2)$ & $7(2)$ \\
\hline C (33) & $40(2)$ & $40(2)$ & $40(2)$ & $7(2)$ & $0(2)$ & $4(2)$ \\
\hline C (34) & $55(2)$ & $44(2)$ & $22(2)$ & $-2(2)$ & $0(2)$ & $8(2)$ \\
\hline C (35) & $68(3)$ & $40(2)$ & $36(2)$ & $-8(2)$ & $-2(2)$ & $16(2)$ \\
\hline C (36) & $64(3)$ & $40(2)$ & $57(3)$ & $17(2)$ & $-4(2)$ & $1(2)$ \\
\hline C (37) & $49(2)$ & $57(2)$ & $50(2)$ & $8(2)$ & $7(2)$ & $22(2)$ \\
\hline C (38) & $61(3)$ & $105(4)$ & $42(3)$ & $12(2)$ & $6(2)$ & $-2(3)$ \\
\hline C (39) & $65(3)$ & $94(4)$ & $61(3)$ & $9(3)$ & $20(2)$ & $18(3)$ \\
\hline C ( 40$)$ & $69(3)$ & $95(4)$ & $76(3)$ & $-23(3)$ & $5(3)$ & $0(3)$ \\
\hline
\end{tabular}

The anisotropic displacement factor exponent takes the form: $-2 \mathrm{pi}^{2}\left[\mathrm{~h}^{2} \mathrm{a} \star^{2} \mathrm{U} 11+\ldots+2 \mathrm{~h} \mathrm{k} a * \mathrm{~b} * \mathrm{U12}\right]$ 
Table A.1.5. Hydrogen coordinates ( $\left.\mathrm{x} 10^{4}\right)$, isotropic displacement parameters $\left(\AA^{2} \times 10^{3}\right)$, and occupancies for $7 \mathbf{b}$

\begin{tabular}{|c|c|c|c|c|c|}
\hline & $x$ & $y$ & $z$ & $\mathrm{U}(\mathrm{eq})$ & Occ. \\
\hline $\mathrm{H}(4)$ & $2820(30)$ & $3130(30)$ & $1889(19)$ & $54(11)$ & 1 \\
\hline $\mathrm{H}(6 \mathrm{~A})$ & 1235 & 2142 & 1666 & 37 & 1 \\
\hline $\mathrm{H}(6 \mathrm{~B})$ & 1516 & 3120 & 2193 & 37 & 1 \\
\hline $\mathrm{H}(7 \mathrm{~A})$ & 385 & 2563 & 2887 & 53 & 1 \\
\hline $\mathrm{H}(7 \mathrm{~B})$ & -228 & 2463 & 2107 & 53 & 1 \\
\hline $\mathrm{H}(8 \mathrm{~A})$ & 138 & 608 & 2118 & 56 & 1 \\
\hline $\mathrm{H}(8 \mathrm{~B})$ & -492 & 912 & 2714 & 56 & 1 \\
\hline $\mathrm{H}(9 \mathrm{~A})$ & 929 & 782 & 3579 & 40 & 1 \\
\hline $\mathrm{H}(9 \mathrm{~B})$ & 968 & -255 & 3106 & 40 & 1 \\
\hline $\mathrm{H}(13 \mathrm{~A})$ & 2774 & -1056 & 4740 & 65 & 1 \\
\hline $\mathrm{H}(13 \mathrm{~B})$ & 2426 & 156 & 4584 & 65 & 1 \\
\hline $\mathrm{H}(13 \mathrm{C})$ & 3602 & -157 & 4674 & 65 & 1 \\
\hline $\mathrm{H}(15 \mathrm{~A})$ & 6137 & 1065 & 3584 & 44 & 1 \\
\hline $\mathrm{H}(15 \mathrm{~B})$ & 6028 & 312 & 2914 & 44 & 1 \\
\hline $\mathrm{H}(16)$ & 7738 & 978 & 3200 & 47 & 1 \\
\hline $\mathrm{H}(17 \mathrm{~A})$ & 7356 & 2675 & 3705 & 60 & 1 \\
\hline $\mathrm{H}(17 \mathrm{~B})$ & 8004 & 2900 & 3105 & 60 & 1 \\
\hline $\mathrm{H}(18)$ & 6608 & 4084 & 2991 & 54 & 1 \\
\hline $\mathrm{H}(19 \mathrm{~A})$ & 4907 & 3404 & 2729 & 47 & 1 \\
\hline $\mathrm{H}(19 \mathrm{~B})$ & 5451 & 2962 & 3472 & 47 & 1 \\
\hline $\mathrm{H}(20 \mathrm{~A})$ & 5209 & 946 & 1744 & 48 & 1 \\
\hline $\mathrm{H}(20 \mathrm{~B})$ & 4732 & 2121 & 1632 & 48 & 1 \\
\hline $\mathrm{H}(21)$ & 6343 & 2120 & 1256 & 56 & 1 \\
\hline $\mathrm{H}(22 \mathrm{~A})$ & 7846 & 1684 & 2057 & 58 & 1 \\
\hline $\mathrm{H}(22 \mathrm{~B})$ & 7085 & 685 & 1971 & 58 & 1 \\
\hline $\mathrm{H}(23 \mathrm{~A})$ & 7120 & 3597 & 1933 & 60 & 1 \\
\hline $\mathrm{H}(23 \mathrm{~B})$ & 5911 & 3753 & 1796 & 60 & 1 \\
\hline $\mathrm{H}(29 \mathrm{~A})$ & 5543 & -3946 & 5509 & 50 & 1 \\
\hline $\mathrm{H}(29 \mathrm{~B})$ & 6241 & -3113 & 6005 & 50 & 1 \\
\hline $\mathrm{H}(30)$ & 6536 & -4895 & 6473 & 58 & 1 \\
\hline $\mathrm{H}(31 \mathrm{~A})$ & 7945 & -3689 & 6679 & 62 & 1 \\
\hline $\mathrm{H}(31 \mathrm{~B})$ & 8348 & -4885 & 6616 & 62 & 1 \\
\hline $\mathrm{H}(32)$ & 9187 & -3717 & 5937 & 55 & 1 \\
\hline $\mathrm{H}(33 \mathrm{~A})$ & 8210 & -2768 & 4973 & 49 & 1 \\
\hline $\mathrm{H}(33 \mathrm{~B})$ & 7862 & -2396 & 5680 & 49 & 1 \\
\hline $\mathrm{H}(34 \mathrm{~A})$ & 7089 & -4105 & 4163 & 49 & 1 \\
\hline $\mathrm{H}(34 \mathrm{~B})$ & 6072 & -4562 & 4382 & 49 & 1 \\
\hline $\mathrm{H}(35)$ & 7413 & -5875 & 4633 & 59 & 1 \\
\hline $\mathrm{H}(36 \mathrm{~A})$ & 6170 & -5852 & 5394 & 66 & 1 \\
\hline $\mathrm{H}(36 \mathrm{~B})$ & 7252 & -6222 & 5824 & 66 & 1 \\
\hline $\mathrm{H}(37 \mathrm{~A})$ & 8881 & -5488 & 5495 & 63 & 1 \\
\hline $\mathrm{H}(37 \mathrm{~B})$ & 8825 & -4668 & 4860 & 63 & 1 \\
\hline $\mathrm{H}(38 \mathrm{~A})$ & 9698 & 553 & 5569 & 84 & 1 \\
\hline $\mathrm{H}(38 \mathrm{~B})$ & 10692 & 837 & 5259 & 84 & 1 \\
\hline $\mathrm{H}(39 \mathrm{~A})$ & 9706 & 1432 & 4225 & 87 & 1 \\
\hline $\mathrm{H}(39 \mathrm{~B})$ & 8689 & 1053 & 4476 & 87 & 1 \\
\hline $\mathrm{H}(40 \mathrm{~A})$ & 8869 & 2904 & 4606 & 122 & 1 \\
\hline $\mathrm{H}(40 \mathrm{~B})$ & 9952 & 2752 & 5098 & 122 & 1 \\
\hline $\mathrm{H}(40 \mathrm{C})$ & 8941 & 2368 & 5356 & 122 & 1 \\
\hline
\end{tabular}




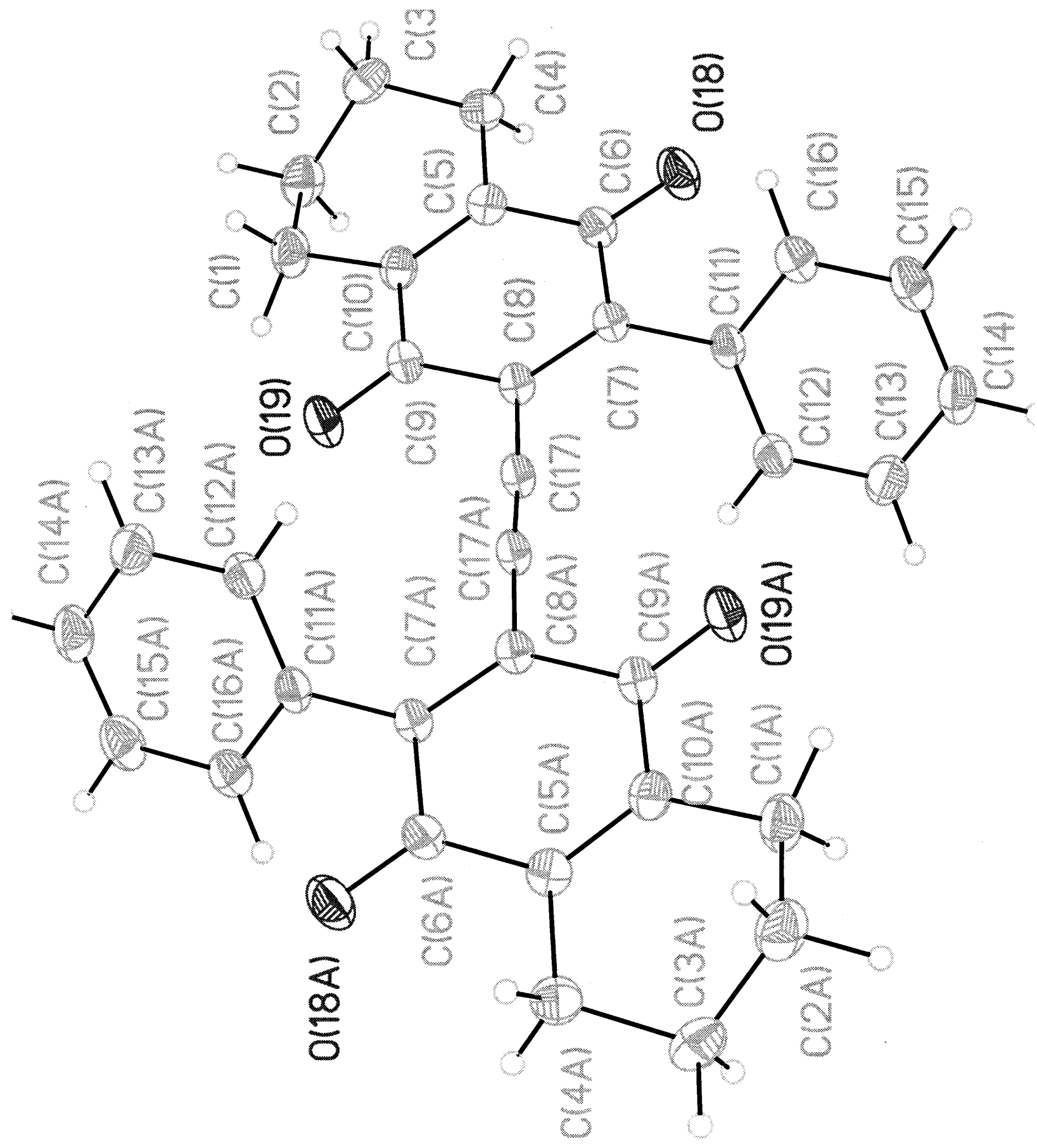

ORTEP Drawing for bis-Quinone 23. 
Table A.2.1 Crystal data and structure refinement for $\mathbf{2 3}$

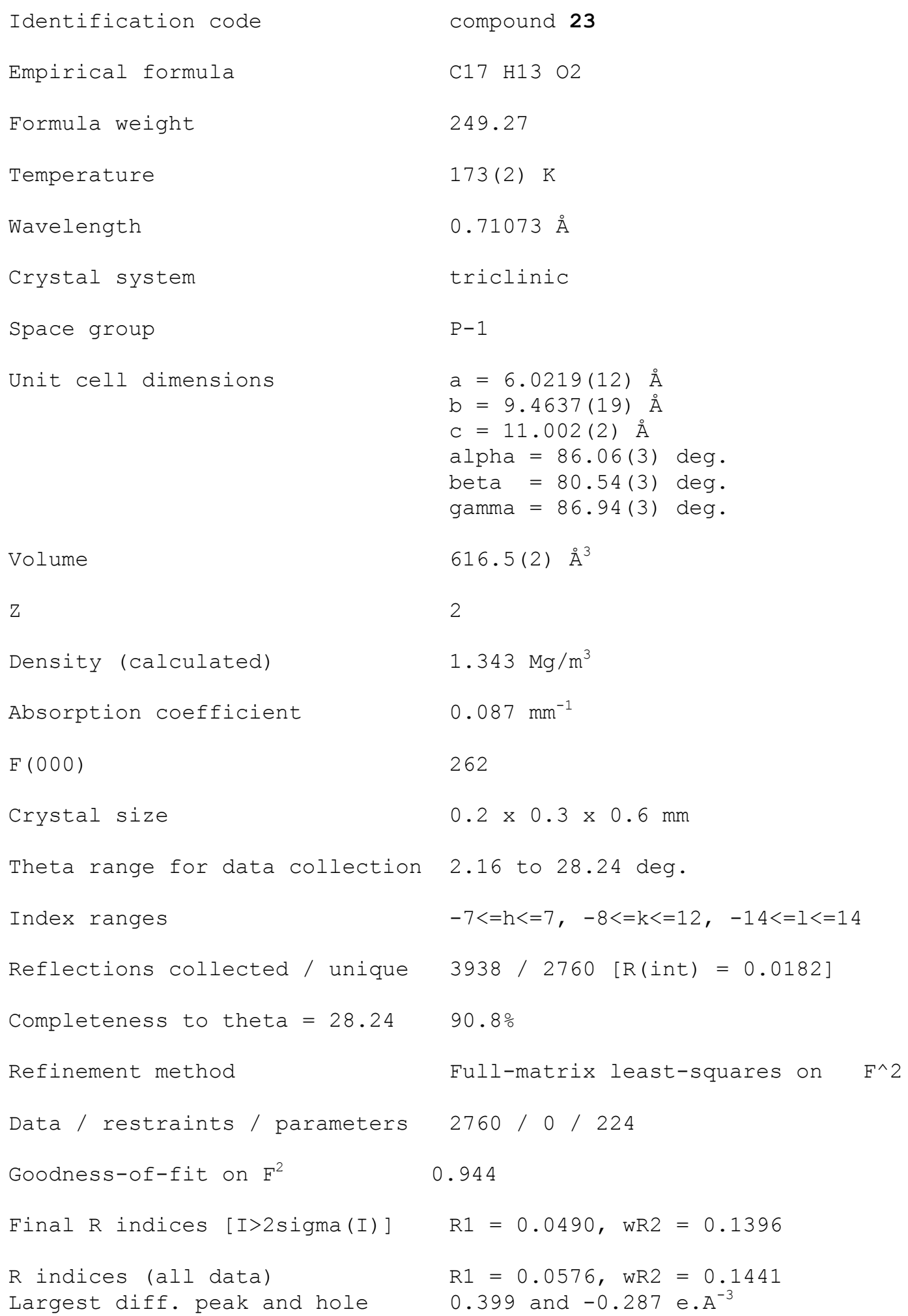


Table A.2.2. Atomic coordinates ( $\left.\mathrm{x} 10^{4}\right)$, equivalent isotropic displacement parameters $\left(\AA^{2} \times 10^{3}\right)$, and occupancies for 23

\begin{tabular}{|c|c|c|c|c|c|}
\hline & $x$ & Y & $z$ & $\mathrm{U}(\mathrm{eq})$ & Occ. \\
\hline C (1) & $5562(3)$ & $1836(2)$ & $1604(1)$ & $33(1)$ & 1 \\
\hline$C(2)$ & $7213(3)$ & $557(2)$ & $1392(1)$ & $35(1)$ & 1 \\
\hline C (3) & $9223(3)$ & $719(2)$ & $2039(1)$ & $33(1)$ & 1 \\
\hline C (4) & $8481(2)$ & $734(2)$ & $3434(1)$ & $28(1)$ & 1 \\
\hline$C(5)$ & $6395(2)$ & $1677(1)$ & $3771(1)$ & $24(1)$ & 1 \\
\hline$C(6)$ & $5786(2)$ & $1980(1)$ & $5091(1)$ & $23(1)$ & 1 \\
\hline$C(7)$ & $3778(2)$ & $2952(1)$ & $5490(1)$ & $21(1)$ & 1 \\
\hline C ( 8) & $2567(2)$ & $3532(1)$ & $4630(1)$ & $22(1)$ & 1 \\
\hline C (9) & $3112(2)$ & $3152(1)$ & $3309(1)$ & $23(1)$ & 1 \\
\hline$C(10)$ & $5100(2)$ & $2183(1)$ & $2939(1)$ & $24(1)$ & 1 \\
\hline C (11) & $3193(2)$ & $3209(1)$ & $6820(1)$ & $22(1)$ & 1 \\
\hline $\mathrm{C}(12)$ & $1019(2)$ & $2975(1)$ & $7440(1)$ & $26(1)$ & 1 \\
\hline C (13) & $470(3)$ & $3193(2)$ & $8696(1)$ & $33(1)$ & 1 \\
\hline $\mathrm{C}(14)$ & $2064(3)$ & $3677(2)$ & $9328(1)$ & $35(1)$ & 1 \\
\hline$C(15)$ & 4209 (3) & $3930(2)$ & $8710(1)$ & $34(1)$ & 1 \\
\hline$C(16)$ & $4797(2)$ & $3679(1)$ & $7464(1)$ & $27(1)$ & 1 \\
\hline C (17) & $737(2)$ & $4551(1)$ & $4910(1)$ & $23(1)$ & 1 \\
\hline$O(18)$ & $6882(2)$ & $1433(1)$ & $5853(1)$ & $37(1)$ & 1 \\
\hline O (19) & $1940(2)$ & $3634(1)$ & $2563(1)$ & 31 (1) & 1 \\
\hline
\end{tabular}

$\mathrm{U}(\mathrm{eq})$ is defined as one third of the trace of the orthogonalized Uij tensor. 
Table A.2.3. Bond lengths [A] and angles [deg] for 23

$\begin{array}{ll}C(1)-C(10) & 1.5045(18) \\ C(1)-C(2) & 1.530(2) \\ C(2)-C(3) & 1.520(2) \\ C(3)-C(4) & 1.528(2) \\ C(4)-C(5) & 1.5116(18) \\ C(5)-C(10) & 1.3452(19) \\ C(5)-C(6) & 1.4829(18) \\ C(6)-O(18) & 1.2215(16) \\ C(6)-C(7) & 1.5047(17) \\ C(7)-C(8) & 1.3563(17) \\ C(7)-C(11) & 1.4810(16) \\ C(8)-C(17) & 1.4337(18) \\ C(8)-C(9) & 1.5005(17) \\ C(9)-O(19) & 1.2186(16) \\ C(9)-C(10) & 1.4878(18) \\ C(11)-C(12) & 1.3943(19) \\ C(11)-C(16) & 1.3961(19) \\ C(12)-C(13) & 1.3939(19) \\ C(13)-C(14) & 1.387(2) \\ C(14)-C(15) & 1.382(2) \\ C(15)-C(16) & 1.3910(19) \\ C(17)-C(17) \# 1 & 1.198(3) \\ & \\ C(10)-C(1)-C(2) & 111.88(12) \\ C(3)-C(2)-C(1) & 109.84(12) \\ C(2)-C(3)-C(4) & 110.70(12) \\ C(5)-C(4)-C(3) & 112.12(12) \\ C(10)-C(5)-C(6) & 121.05(11) \\ C(10)-C(5)-C(4) & 122.64(12) \\ C(6)-C(5)-C(4) & 116.27(11) \\ O(18)-C(6)-C(5) & 120.48(11) \\ O(18)-C(6)-C(7) & 120.14(11) \\ C(5)-C(6)-C(7) & 119.36(11) \\ C(8)-C(7)-C(11) & 123.04(11) \\ C(8)-C(7)-C(6) & 119.08(11) \\ C(11)-C(7)-C(6) & 117.87(11) \\ C(7)-C(8)-C(17) & 122.85(11) \\ C(7)-C(8)-C(9) & 121.19(11) \\ C(17)-C(8)-C(9) & 115.95(11) \\ O(19)-C(9)-C(10) & 121.23(11) \\ O(19)-C(9)-C(8) & 120.14(11) \\ C(10)-C(9)-C(8) & 118.63(11) \\ C(5)-C(10)-C(9) & 120.45(11) \\ C(5)-C(10)-C(1) & 123.23(12) \\ C(9)-C(10)-C(1) & 116.32(11) \\ C(12)-C(11)-C(16) & 119.40(12) \\ C(12)-C(11)-C(7) & 119.86(12) \\ C(16)-C(11)-C(7) & 120.75(12) \\ C(11)-C(12)-C(13) & 120.07(13) \\ C(14)-C(13)-C(12) & \\ C(15)-C(14)-C(13) & 119.70(13) \\ C(14)-C(15)-C(16) & \\ & 120) \\ C(14) & \end{array}$


$\mathrm{C}(15)-\mathrm{C}(16)-\mathrm{C}(11)$

$\mathrm{C}(17) \# 1-\mathrm{C}(17)-\mathrm{C}(8)$
$119.92(13)$

$176.42(18)$

Symmetry transformations used to generate equivalent atoms: \# $1-x,-y+1,-z+1$ 
Table A.2.4. Anisotropic displacement parameters ( $\mathrm{A} \times 10^{3}$ ) for 23

\begin{tabular}{|c|c|c|c|c|c|c|}
\hline & U11 & U22 & U33 & U23 & U13 & $\mathrm{U} 12$ \\
\hline C (1) & $40(1)$ & 37 (1) & $20(1)$ & $-6(1)$ & $-4(1)$ & $6(1)$ \\
\hline C (2) & $43(1)$ & $34(1)$ & 27 (1) & $-9(1)$ & $-1(1)$ & $4(1)$ \\
\hline C (3) & $32(1)$ & $33(1)$ & $32(1)$ & $-6(1)$ & $4(1)$ & $2(1)$ \\
\hline$C(4)$ & $27(1)$ & $28(1)$ & $29(1)$ & $-3(1)$ & $-3(1)$ & $3(1)$ \\
\hline$C(5)$ & $26(1)$ & 21 (1) & $24(1)$ & $-2(1)$ & $-4(1)$ & $0(1)$ \\
\hline$C(6)$ & $25(1)$ & 23 (1) & 23 (1) & $-1(1)$ & $-7(1)$ & $1(1)$ \\
\hline C ( 7) & $24(1)$ & 22 (1) & $19(1)$ & $-1(1)$ & $-6(1)$ & $0(1)$ \\
\hline$C(8)$ & $25(1)$ & 21 (1) & $19(1)$ & $-1(1)$ & $-5(1)$ & $0(1)$ \\
\hline$C(9)$ & $28(1)$ & 22 (1) & $19(1)$ & $-1(1)$ & $-6(1)$ & $-1(1)$ \\
\hline$C(10)$ & $29(1)$ & $23(1)$ & 21 (1) & $-2(1)$ & $-3(1)$ & $-1(1)$ \\
\hline C (11) & $27(1)$ & 22 (1) & $17(1)$ & $0(1)$ & $-6(1)$ & $4(1)$ \\
\hline $\mathrm{C}(12)$ & $28(1)$ & $30(1)$ & 23 (1) & $0(1)$ & $-7(1)$ & $2(1)$ \\
\hline C (13) & $34(1)$ & $39(1)$ & $23(1)$ & 1 (1) & $0(1)$ & $6(1)$ \\
\hline C (14) & 45 (1) & $40(1)$ & $19(1)$ & $-5(1)$ & $-6(1)$ & $12(1)$ \\
\hline$C(15)$ & 42 (1) & 37 (1) & $26(1)$ & $-9(1)$ & $-15(1)$ & $4(1)$ \\
\hline C (16) & $30(1)$ & 28 (1) & 25 (1) & $-4(1)$ & $-9(1)$ & $1(1)$ \\
\hline C (17) & $28(1)$ & $26(1)$ & $16(1)$ & $0(1)$ & $-7(1)$ & $0(1)$ \\
\hline O (18) & $39(1)$ & 45 (1) & 29 (1) & $-4(1)$ & $-14(1)$ & $16(1)$ \\
\hline O (19) & $38(1)$ & $35(1)$ & $23(1)$ & $-4(1)$ & $-13(1)$ & $6(1)$ \\
\hline
\end{tabular}

The anisotropic displacement factor exponent takes the form: $-2 \mathrm{pi}^{2}\left[\mathrm{~h}^{2} \mathrm{a}^{2} \mathrm{U} 11+\ldots+2 \mathrm{~h} \mathrm{k} \mathrm{a}^{*} \mathrm{~b} * \mathrm{U} 12\right]$ 
Table A.2.5. Hydrogen coordinates $\left(\times 10^{4}\right)$, isotropic displacement parameters $\left(\AA^{2} \times 10^{3}\right)$, and occupancies for 23

\begin{tabular}{|c|c|c|c|c|c|}
\hline $\mathrm{x}$ & $\mathrm{Y}$ & z & $\mathrm{U}(\mathrm{eq})$ & Occ. & \\
\hline$H(1 A)$ & $4070(30)$ & $1670(20)$ & $1331(18)$ & $47(5)$ & 1 \\
\hline $\mathrm{H}(1 \mathrm{~B})$ & $6150(30)$ & $2700(20)$ & $1104(17)$ & $46(5)$ & 1 \\
\hline $\mathrm{H}(2 \mathrm{~A})$ & $6430(30)$ & $-340(20)$ & $1723(16)$ & $36(4)$ & 1 \\
\hline $\mathrm{H}(2 \mathrm{~B})$ & $7680(30)$ & $486(19)$ & $448(16)$ & $35(4)$ & 1 \\
\hline $\mathrm{H}(3 \mathrm{~A})$ & $10430(30)$ & $-50(20)$ & $1857(16)$ & $41(5)$ & 1 \\
\hline $\mathrm{H}(3 \mathrm{~B})$ & $9920(30)$ & 1641 (19) & $1736(15)$ & $30(4)$ & 1 \\
\hline $\mathrm{H}(4 \mathrm{~A})$ & $9670(30)$ & $1058(18)$ & $3811(16)$ & $33(4)$ & 1 \\
\hline $\mathrm{H}(4 \mathrm{~B})$ & $8120(30)$ & $-259(19)$ & $3802(16)$ & $35(4)$ & 1 \\
\hline $\mathrm{H}(12)$ & $-110(30)$ & $2615(18)$ & $7010(14)$ & $30(4)$ & 1 \\
\hline $\mathrm{H}(13)$ & $-1000(30)$ & $2990(20)$ & $9085(17)$ & $42(5)$ & 1 \\
\hline $\mathrm{H}(14)$ & $1660(30)$ & $3820(20)$ & $10178(19)$ & $51(5)$ & 1 \\
\hline $\mathrm{H}(15)$ & $5370(30)$ & $4280(20)$ & $9139(18)$ & $46(5)$ & 1 \\
\hline $\mathrm{H}(16)$ & $6330(30)$ & $3843(19)$ & $7056(15)$ & $35(4)$ & 1 \\
\hline
\end{tabular}


Table A.2.6. Torsion angles [deg] for 23

\begin{tabular}{|c|c|c|}
\hline$C(10)$ & ) $\quad C(1) \quad C(2) \quad C(3)$ & $-47.17(17)$ \\
\hline$C(1)$ & $C(2) \quad C(3) \quad C(4)$ & $63.14(16)$ \\
\hline$C(2)$ & $C(3)$ & $-45.16(16)$ \\
\hline$C(3)$ & $C(10)$ & $13.34(19)$ \\
\hline$C(3)$ & $C(4) \quad C(5) \quad C(6)$ & $-168.84(12)$ \\
\hline$C(10)$ & ) $\mathrm{C}(5) \quad \mathrm{C}(6) \quad \mathrm{O}(18)$ & $174.75(13)$ \\
\hline$C(4)$ & $\mathrm{C}(5) \quad \mathrm{C}(6) \quad \mathrm{O}(18)$ & $-3.11(19)$ \\
\hline$C(10)$ & ) $C(5) \quad C(6) \quad C(7)$ & $-4.27(19)$ \\
\hline$C(4)$ & $C(5) \quad C(6) \quad C(7)$ & $177.87(11)$ \\
\hline$O(18)$ & ) $C(6) \quad C(7) \quad C(8)$ & $-179.07(12)$ \\
\hline$C(5)$ & $C(6) \quad C(7) \quad C(8)$ & $-0.04(18)$ \\
\hline$O(18)$ & ) $C(6) \quad C(7) \quad C(11)$ & $-0.23(19)$ \\
\hline$C(5)$ & $C(6) \quad C(7) \quad C(11)$ & $178.80(11)$ \\
\hline $\mathrm{C}(11)$ & ) $\mathrm{C}(7) \quad \mathrm{C}(8) \quad \mathrm{C}(17)$ & $6.1(2)$ \\
\hline$C(6)$ & $C(7) \quad C(8) \quad C(17)$ & $-175.12(11)$ \\
\hline $\mathrm{C}(11)$ & ) $C(7) \quad C(8) \quad C(9)$ & $-175.09(11)$ \\
\hline$C(6)$ & $C(7) \quad C(8) \quad C(9)$ & $3.69(18)$ \\
\hline$C(7)$ & $\mathrm{C}(8) \quad \mathrm{C}(9) \quad \mathrm{O}(19)$ & $176.63(12)$ \\
\hline$C(17)$ & ) $\mathrm{C}(8) \quad \mathrm{C}(9) \quad \mathrm{O}(19)$ & $-4.48(18)$ \\
\hline$C(7)$ & $C(8) \quad C(9) \quad C(10)$ & $-3.42(18)$ \\
\hline$C(17)$ & ) $C(8) \quad C(9) \quad C(10)$ & $47(11)$ \\
\hline$C(6)$ & $C(5) \quad C(10)$ & $4.6(2)$ \\
\hline$C(4)$ & $C(10)$ & $-177.69(11)$ \\
\hline$C(6)$ & $C(10) \quad C(1)$ & $-176.21(12)$ \\
\hline$C(4)$ & $C(5) \quad C(10) \quad C(1)$ & $1.5(2)$ \\
\hline$O(19)$ & ) $C(9) \quad C(10) \quad C(5)$ & $179.04(12)$ \\
\hline$C(8)$ & $C(9) \quad C(10) \quad C(5)$ & $-0.91(19)$ \\
\hline$O(19)$ & ) $C(9) \quad C(10) \quad C(1)$ & $-0.22(19)$ \\
\hline$C(8)$ & $C(9) \quad C(10) \quad C(1)$ & $179.83(11)$ \\
\hline$C(2)$ & $C(10) \quad C(5)$ & $15.8(2)$ \\
\hline$C(2)$ & $C(10) \quad C(9)$ & $-164.94(12)$ \\
\hline $\mathrm{C}(8)$ & C (12) & $52.72(18)$ \\
\hline$C(6)$ & $C(11) \quad C(12)$ & $-126.07(13)$ \\
\hline $\mathrm{C}(8)$ & $\mathrm{C}(7) \quad \mathrm{C}(11) \quad \mathrm{C}(16)$ & $-127.46(14)$ \\
\hline$C(6)$ & $C(7) \quad C(11) \quad C(16)$ & $53.74(16)$ \\
\hline$C(16)$ & ) $C(11) \quad C(12) \quad C(13)$ & $-0.84(19)$ \\
\hline$C(7)$ & $C(11) \quad C(12) \quad C(13)$ & $178.99(11)$ \\
\hline $\mathrm{C}(11)$ & ) $C(12) \quad C(13) \quad C(14)$ & $1.6(2)$ \\
\hline$C(12)$ & ) $\quad C(13) \quad C(14) \quad C(15)$ & $-0.6(2)$ \\
\hline$C(13)$ & $C(15)$ & $-1.2(2)$ \\
\hline$C(14)$ & $C(15)$ & $2.0(2)$ \\
\hline$C(12)$ & ) $C(11) \quad C(16) \quad C(15)$ & $-0.94(19)$ \\
\hline$C(7)$ & $C(11) \quad C(16) \quad C(15)$ & $179.24(12)$ \\
\hline$C(7)$ & $C(8) \quad C(17) \quad C(17) \# 1$ & \\
\hline$C(9)$ & $\mathrm{C}(17) \# 1$ & $-50(3)$ \\
\hline
\end{tabular}
$z+1$

Symmetry transformations used to generate equivalent atoms: \#1 $-\mathrm{x},-\mathrm{y}+1,-$ 